\title{
Gut Microbiota, Probiotics and Physical Performance in Athletes and Physically Active Individuals
}

\author{
Maija Marttinen *, Reeta Ala-Jaakkola, Arja Laitila and Markus J. Lehtinen \\ DuPont Nutrition \& Biosciences, Danisco Sweeteners Oy, Sokeritehtaantie 20, 02460 Kantvik, Finland; \\ reeta.ala-jaakkola@dupont.com (R.A.-J.); arja.laitila@dupont.com (A.L.); markus.lehtinen@dupont.com (M.J.L.) \\ * Correspondence: maija.marttinen@dupont.com; Tel.: +358-40-820-6151
}

Received: 25 August 2020; Accepted: 24 September 2020; Published: 25 September 2020

\begin{abstract}
Among athletes, nutrition plays a key role, supporting training, performance, and postexercise recovery. Research has primarily focused on the effects of diet in support of an athletic physique; however, the role played by intestinal microbiota has been much neglected. Emerging evidence has shown an association between the intestinal microbiota composition and physical activity, suggesting that modifications in the gut microbiota composition may contribute to physical performance of the host. Probiotics represent a potential means for beneficially influencing the gut microbiota composition/function but can also impact the overall health of the host. In this review, we provide an overview of the existing studies that have examined the reciprocal interactions between physical activity and gut microbiota. We further evaluate the clinical evidence that supports the effects of probiotics on physical performance, post-exercise recovery, and cognitive outcomes among athletes. In addition, we discuss the mechanisms of action through which probiotics affect exercise outcomes. In summary, beneficial microbes, including probiotics, may promote health in athletes and enhance physical performance and exercise capacity. Furthermore, high-quality clinical studies, with adequate power, remain necessary to uncover the roles that are played by gut microbiota populations and probiotics in physical performance and the modes of action behind their potential benefits.
\end{abstract}

Keywords: gut microbiota; probiotics; athletes; exercise; physical activity; physical performance; cognitive performance; recovery

\section{Introduction}

The human gastrointestinal (GI) tract harbors a vast number of microbial cells $\left(10^{14}\right)$, which surpasses the number of cells that make up the human body [1]. Although many intestinal microbiota species are beneficial, others are potentially detrimental, or their functions remain unknown. These resident microbes are involved in many metabolic processes, such as the fermentation of undigested carbohydrates into short-chain fatty acids (SCFAs), lipid metabolism, and vitamin synthesis. Intestinal microbiota also stimulates the maturation of the immune system and protects against potentially pathogenic microbes [2]. Further, the microbiota may play a role in cognitive performance and stress tolerance $[3,4]$.

A healthy adult gut is characterized by a high degree of microbial richness (diversity) [5], favoring health-promoting species, and features an intact epithelial barrier, which affects the inflammatory status and nutrient utilization of the host [6]. Genetic and environmental factors, in addition to diet and antibiotic use, have major influences on the gut microbiota composition, starting in early childhood and extending into adulthood [7]. Dysbiosis and the loss of diversity among gut microbiota species have been associated with various immune-regulated pathological conditions and diseases and may, in part, contribute to the risks of developing obesity-related disorders $[7,8]$. 
Gut microbiota populations with high degrees of microbial diversity have been associated with various health benefits in adults. Gut microbes have the potential to exert effects via metabolites, such as SCFAs and neurotransmitters, that can influence mucosal tissues locally or enter the circulation to affect extra-intestinal tissues. Recently, these findings have resulted in the conceptualization of a gut-brain axis (for review see [9]) and a gut-muscle axis (for review see [10]) indicating the existence of bidirectional communications between the gut microbiota and the peripheral tissues of the host.

Exercise has well-known effects on cardiorespiratory fitness, muscle strength, glucose metabolism, the immune system, and mental health [11]. Emerging evidence has indicated a plausible association between physical activity and the gut microbiota composition [12-14]. The particular features of gut microbiota compositions found in athletic individuals and the impacts of exercise on the gut microbiota compositions of sedentary populations have begun to be revealed. Intervention studies have supported the beneficial impacts of exercise and physical activity on the gut microbiota [15-17]. Furthermore, a growing interest has developed regarding whether the modification of the gut microbiota composition can affect the exercise and training outcomes of the host.

Probiotics are, by definition, "live micro-organisms that, when administered in adequate amounts, confer a health benefit on the host" [18]. Probiotic supplementation may modify the gut microbiota composition, promoting increased microbial diversity and supporting the growth of health-promoting species [19-21]. Probiotics may also help restore a disturbed gut microbiota [15] and support a microbiota under stress [22,23]. Although, many probiotics can support a general healthy GI and immune system function, the specific mechanisms underlying probiotic actions, such as the production of bioactive compounds, the inhibition of pathogen adhesion, the improvement of gut barrier function, and immune modulation, may be highly strain-specific, even within a single bacterial species [18].

Thus far, probiotic research has primarily focused on GI function and immune regulation; however, recent studies have targeted new research areas, such as metabolic and cognitive health. The well-established probiotic effects on gut health and immune system function may benefit endurance athletes, who train and perform at high intensities and often encounter physiological challenges associated with GI and immune health during and after a competition. Therefore, probiotic supplementation may indirectly improve the performance of an athlete by increasing the number of healthy training and competition days and maybe even benefit stamina. The benefits of probiotics for sports performance and training have been recognized, although the number of studies that have examined these issues remains limited. Recently, the International Society of Sports Nutrition (ISSN) provided a position stand on probiotics, concluding that probiotics have strain-specific effects in athletes [24]. In this review, we provide an overview of the current research on the relationships between exercise and gut microbiota and further evaluate the indirect and direct effects of probiotics on physical performance, in animal models and human subjects.

\section{Gut Microbiota and Physical Performance}

Exercise has well-known effects on metabolism and the immune system, but the effects of exercise on the gut microbiota have been less well studied. Compared with sedentary subjects, athletes and physically active subjects appear to have greater fecal microbial diversity and more health-associated microbial genera, such as Akkermansia, Veillonella and Prevotella [12-14]. However, the results of these observational studies can only confirm associations between training status and microbiota populations, without determining causality. In addition to physical activity patterns, sedentary subjects often differ from physically active subjects in dietary intake patterns [25], and diet has a strong impact on the gut microbiota composition [26].

The association between exercise and the gut microbiota composition appears to be bidirectional. Exercise intervention studies in humans have indicated that regular physical activity modulates the gut microbial composition [15-17]. Furthermore, growing evidence from animal studies has also suggested that the gut microbiota plays an important role in the physical performance of the host [27-29]. The composition and metabolic activity of gut microbiota may aid in the digestion of 
dietary compounds and improve energy harvest during exercise, which could provide metabolic benefits for an athlete during high-intensity exercise and recovery. Observational studies have demonstrated that the metabolic activity and pathways associated with amino acid and carbohydrate metabolism are increased among the athlete microbiome compared with those in sedentary subjects $[13,14,30]$.

In the gut, bacteria ferment non-digestible carbohydrates, primarily into SCFAs acetate, propionate and butyrate. Training and regular exercise have been associated with increased fecal SCFA contents in humans [15,30], and specific SCFAs have been associated with improved physical performance in animal studies [14,29]. Most SCFAs are absorbed from the intestinal tract and contribute to the host's energy metabolism [31]. Butyrate is used primarily by epithelial cells in the colon, as an energy source. Acetate is metabolized in muscle tissue but can also cross the blood-brain barrier. Propionate can be used as a precursor for glucose synthesis in the liver [31]. Additionally, SCFAs improve intestinal barrier integrity, reducing local and systemic inflammation risk. Preclinical studies have strongly suggested that SCFAs may represent key modulators of physical performance.

Notably, the host may not be the only party to benefit from the symbiotic relationship with microbiota during exercise. A recent study suggested that lactate, produced by the host skeletal muscles during anaerobic exercise, enters the gut lumen through circulation, providing a selective advantage for lactate-utilizing species that reside in the colon [14]. The results from this seminal work imply that during high-intensity exercise, the host provides fuel, in the form of lactate, for specific bacteria, which, in turn, produce metabolites, such as propionate, that benefit the exercising host. Current research on the interactions between the gut microbiota and physical performance is reviewed below and summarized in Figure 1.

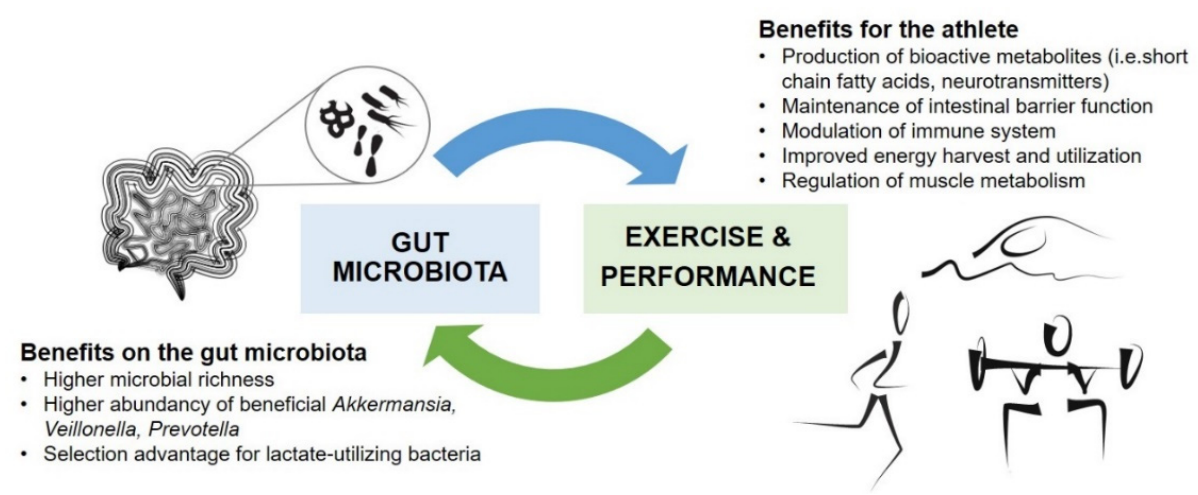

Figure 1. Interactions between gut microbiota and exercise.

\subsection{Gut Microbiota in Athletes}

Accumulating clinical evidence has suggested that exercise modifies the gut microbiota and that the gut microbiota composition in athletes differs from that in sedentary people, with athletes presenting with microbial populations that are enriched in health-promoting species and have greater diversity (Table 1). Diet and specific dietary components, such as dietary fiber, have been identified as major influencers of the gut microbiota composition [26]. In cross-sectional and longitudinal studies, the impacts of diet on gut microbiota cannot be excluded, especially because the dietary intake of an athlete can greatly differ from the intake of a sedentary individual, in terms of both caloric and nutrient contents. Most of the studies in Table 1 have reported dietary intake.

A study involving Irish, male professional rugby players showed a higher $\alpha$-diversity (bacterial richness, such as how many bacterial species are identified in fecal samples) for the gut microbiota of athletes compared with those in sedentary controls [12]. Gut microbiota diversity correlated positively with protein consumption and plasma creatine kinase (CK) levels, a biomarker for exercise-induced muscle damage. A higher proportion of bacteria from the Akkermansia genus was detected in rugby players and controls with low body mass index (BMI) compared with the proportion in controls with high BMI. Bacteroides spp. were significantly less abundant in athletes than in controls with low BMI. 
Table 1. Studies on exercise and gut microbiota conducted in athletes, physically active individuals and sedentary population.

\begin{tabular}{|c|c|c|c|c|}
\hline Subjects & Training Regimen, Exercise Protocol & Dietary Intake & Main Results & Reference \\
\hline \multicolumn{5}{|l|}{ Athletes: } \\
\hline $\begin{array}{l}\text { Rugby players vs. BMI-matched } \\
\text { sedentary controls } \\
\mathrm{n}=86, \text { males } \\
\text { Age } 29 \pm 4 \text { y }\end{array}$ & Habitual training and exercise & $\begin{array}{l}\text { Self-reported intake by FFQ } \\
\text { In athletes, higher total energy, macronutrient and fiber } \\
\text { intake. Protein intake } 22 \mathrm{E} \% \text { in athletes, } 16 \mathrm{E} \% \text { in low-BMI } \\
\text { and } 15 \mathrm{E} \% \text { in high-BMI controls }\end{array}$ & $\begin{array}{l}\text { In athletes, higher } \alpha \text {-diversity and Akkermansia spp. } \\
\text { abundance vs. sedentary controls. Protein intake was } \\
\text { positively correlated with microbial diversity. }\end{array}$ & [12] \\
\hline $\begin{array}{l}\text { Rugby players vs. BMI-matched } \\
\text { sedentary controls } \\
\mathrm{n}=86, \text { males } \\
\text { Age } 29 \pm 4 \text { y }\end{array}$ & Habitual training and exercise & $\begin{array}{l}\text { Self-reported intake by FFQ } \\
\text { In athletes, higher total energy, macronutrient and fiber } \\
\text { intake. Protein } 22 \mathrm{E} \% \text { in athletes vs. } 16 \mathrm{E} \% \text { in low-BMI } \\
\text { and } 15 \mathrm{E} \% \text { in high-BMI controls }\end{array}$ & $\begin{array}{l}\text { In athletes, fecal SCFAs, microbial pathways for } \\
\text { antibiotic biosynthesis, and amino acids and } \\
\text { carbohydrate metabolism were increased. }\end{array}$ & [30] \\
\hline $\begin{array}{l}\text { Professional cyclists vs. } \\
\text { amateur cyclists } \\
\mathrm{n}=33(22 / \mathrm{M}, 11 / \mathrm{F}) \\
\text { Age } 19-49 \mathrm{y}\end{array}$ & Habitual training & $\begin{array}{l}\text { Dietary intake data collected by questionnaire, reported } \\
\text { and analyzed as overall dietary patterns. }\end{array}$ & $\begin{array}{l}\text { Prevotella spp. abundance was positively correlated } \\
\text { with the amount of exercise and branched chain amino } \\
\text { acid and carbohydrate metabolism pathways. } \\
\text { Professional cyclists had increased Methanobrevibacter } \\
\text { smithii transcripts and upregulated genes involved in } \\
\text { the production of methane compared with amateur } \\
\text { cyclists. No correlations between overall diet and gut } \\
\text { microbiota clusters. }\end{array}$ & [13] \\
\hline $\begin{array}{l}\text { Cross-country runners } \\
\mathrm{n}=18 \text {, males } \\
\text { Age: } \\
\text { Control group } 35.4 \pm 9.0 \mathrm{y} \\
\text { Protein group } 34.9 \pm 9.5 \mathrm{y}\end{array}$ & Habitual endurance training & $\begin{array}{l}\text { Habitual diet by FFQ } \\
\text { No differences in habitual dietary intake within or } \\
\text { between groups, at baseline or after the intervention. } \\
\text { Dietary intervention: habitual diet and whey isolate }(10 \mathrm{~g}) \\
+ \text { beef hydrolysate }(10 \mathrm{~g}) \text { or maltodextrin (control) for } 10 \\
\text { weeks }\end{array}$ & $\begin{array}{l}\text { After the intervention, higher Bacteroidetes and lower } \\
\text { Firmicutes abundance in the protein group. } \\
\text { Bifidobacterium longum was reduced after intervention } \\
\text { in the protein group. No changes in microbiota } \\
\text { composition in the control group, from pre- to } \\
\text { post-intervention. No differences within or between } \\
\text { groups in fecal SCFA, before or after the intervention. }\end{array}$ & [32] \\
\hline $\begin{array}{l}\text { Bodybuilders, long-distance } \\
\text { runners vs. sedentary subjects } \\
\mathrm{n}=45 \text {, males } \\
\text { Age: Bodybuilders } 25 \pm 3 \mathrm{y} \\
\text { distance runners } 20 \pm 1 \mathrm{y} \\
\text { sedentary } 26 \pm 2 \mathrm{y}\end{array}$ & Habitual training and exercise & $\begin{array}{l}\text { Self-recorded 3-day food diary } \\
\text { Bodybuilders had a high-protein and distance runners } \\
\text { had a low-dietary-fiber dietary pattern. Dietary fiber } \\
\text { intake was below recommendation in all groups. }\end{array}$ & $\begin{array}{l}\text { Compositional differences in bodybuilders and } \\
\text { runners associated with exercise type and diet. } \\
\text { No difference in microbial diversity between groups. } \\
\text { In distance runners, protein intake was negatively } \\
\text { correlated with microbial diversity. }\end{array}$ & [33] \\
\hline $\begin{array}{l}\text { Highly trained ultra-endurance } \\
\text { rowers } \\
\mathrm{n}=4 \text {, males } \\
\text { Age } 26.5 \pm 1.3 \text { y }\end{array}$ & ca. $5000 \mathrm{~km}$ rowing race over 34 days & $\begin{array}{l}\text { Self-reported intake (FFQ), detailed daily record pre-race } \\
\text { and during the race } \\
\text { No fresh produce consumed during race. Pre-race fiber } \\
\text { intake: } 21.45 \mathrm{~g} / \text { day, intra-race } 23.1 \mathrm{~g} / \text { day. Only small } \\
\text { changes in intra-race macronutrient intake compared with } \\
\text { pre-race }\end{array}$ & $\begin{array}{l}\text { After the race, increased diversity and } \\
\text { butyrate-producing species including } \\
\text { Roseburia hominis and changes in microbial } \\
\text { composition were observed. }\end{array}$ & [34] \\
\hline
\end{tabular}


Table 1. Cont.

\begin{tabular}{|c|c|c|c|c|}
\hline Subjects & Training Regimen, Exercise Protocol & Dietary Intake & Main Results & Reference \\
\hline $\begin{array}{l}\text { Elite race walkers } \\
\mathrm{n}=21 \text {, males } \\
\text { Age } 20-35 \text { y }\end{array}$ & $\begin{array}{l}\text { 3-week structured program of } \\
\text { intensified training }\end{array}$ & $\begin{array}{l}\text { Dietary intervention for } 3 \text { weeks with planned and } \\
\text { individualized menus. Subjects allocated into } \\
\text { High-carbohydrate diet (HCHO) } \\
\text { Periodized-carbohydrate diet (PCHO), or } \\
\text { Low-carbohydrate, high-fat diet (LCHF) (ketogenic) group }\end{array}$ & $\begin{array}{l}\text { At baseline, microbiota profiles could be separated } \\
\text { into Prevotella- or Bacteroides-dominating enterotypes. } \\
\text { HCHO and PCHO resulted in minor changes, whereas } \\
\text { LCHF resulted in stronger changes in microbial } \\
\text { composition. LCHF was associated with reduced } \\
\text { Faecalibacterium, Bifidobacterium, and Veillonella spp. } \\
\text { Increased Bacteroides and Dorea spp. in the LCHF } \\
\text { group was associated with decreased performance. }\end{array}$ & [35] \\
\hline $\begin{array}{l}\text { Marathon runners: } \\
\mathrm{n}=15(4 / \mathrm{M}, 11 / \mathrm{F}) \\
\text { Mean age } 27.1 \mathrm{y} ; \\
\text { Non-runners: } \\
\mathrm{n}=11(5 / \mathrm{M}, 6 / \mathrm{F}) \\
\text { Mean age } 29.2 \mathrm{y} ; \\
\text { Ultramarathon and } \\
\text { rower athletes: } \\
\mathrm{n}=11(5 / \mathrm{M}, 6 / \mathrm{F}) \\
\text { Age not reported }\end{array}$ & $\begin{array}{l}\text { Habitual training and a marathon } \\
\text { Type of exercise not reported for the } \\
\text { cohort of ultra-marathon and rower } \\
\text { athletes }\end{array}$ & Dietary intake data collected by questionnaire & $\begin{array}{l}\text { In marathon runners, the relative abundance of } \\
\text { Veillonella spp. increased post-marathon. } \\
\text { In ultramarathon and rower athletes, the relative } \\
\text { abundance of the methylmalonyl-CoA pathway } \\
\text { (degrading lactate into propionate) in the gut } \\
\text { microbiome increased post-exercise. No correlations } \\
\text { between dairy, protein, grains, fruits, or vegetables } \\
\text { and Veillonella spp. abundance was observed among } \\
\text { marathon runners. }\end{array}$ & [14] \\
\hline \multicolumn{5}{|c|}{ Non-athletes and sedentary subjects: } \\
\hline $\begin{array}{l}\text { Healthy subjects } \\
\mathrm{n}=39(22 / \mathrm{M}, 17 / \mathrm{F}) \\
\text { Age } 18-35 \mathrm{y}\end{array}$ & $\begin{array}{l}\mathrm{VO}_{2} \text { Peak test to assess } \mathrm{CRF} \text { and to } \\
\text { allocate subjects into groups (low, } \\
\text { average, and high CRF) }\end{array}$ & $\begin{array}{l}\text { 24-h dietary recall interview } \\
\text { No significant differences in dietary intake } \\
\text { between groups. }\end{array}$ & $\begin{array}{l}\text { CRF correlated with microbial diversity and } \\
\text { butyrate production. }\end{array}$ & [36] \\
\hline $\begin{array}{l}\text { Active vs. sedentary women } \\
\mathrm{n}=40 \\
\text { Active: } 30.7 \pm 5.9 \mathrm{y} \\
\text { BMI } 24.4 \pm 4.5 \mathrm{~kg} / \mathrm{m}^{2} \\
\text { Sedentary: } 32.2 \pm 8.7 \mathrm{y} \\
\text { BMI } 22.9 \pm 3.0 \mathrm{~kg} / \mathrm{m}^{2}\end{array}$ & $\begin{array}{l}\text { Habitual physical activity measured } \\
\text { by accelerometer. }\end{array}$ & $\begin{array}{l}\text { Self-reported food intake }(\mathrm{FFQ}) \\
\text { Fiber, fruit, and vegetable intake significantly higher in } \\
\text { the active group. }\end{array}$ & $\begin{array}{l}\text { Higher abundance of Faecalibacterium prausnitzii, } \\
\text { Roseburia hominis and Akkermansia muciniphila in active } \\
\text { women. Physical activity was not associated with } \\
\text { differences in microbiota richness. }\end{array}$ & [37] \\
\hline $\begin{array}{l}\text { Lean and obese sedentary } \\
\text { subjects } \\
\mathrm{n}=32 \\
\text { Lean: } \mathrm{n}=18(9 / \mathrm{M}, 9 / \mathrm{F}) \text {, mean } \\
\text { age } 25.10 \mathrm{y} ; \\
\text { Obese: } \mathrm{n}=14(3 / \mathrm{M}, 11 / \mathrm{F}) \text {, mean } \\
\text { age } 31.14 \mathrm{y}\end{array}$ & $\begin{array}{l}\text { Exercise intervention study: } 6 \text { weeks } \\
\text { of moderate-to-vigorous intensity } \\
\text { aerobic exercise and } 6 \text { weeks } \\
\text { without exercise }\end{array}$ & $\begin{array}{l}\text { Maintenance of habitual diet during the intervention. } \\
\text { A designed 3-day food menu, based on previous reported } \\
\text { habitual diet, before fecal sample collection. }\end{array}$ & $\begin{array}{l}\text { At baseline, the composition of gut microbiota differed } \\
\text { between lean and obese subjects, but after exercise } \\
\text { training, no difference } \\
\text { was observed between lean and obese subjects. } \\
\text { Exercise increased fecal SCFA and SCFA producing } \\
\text { bacteria in lean subjects. }\end{array}$ & [15] \\
\hline
\end{tabular}


Table 1. Cont.

\begin{tabular}{|c|c|c|c|c|}
\hline Subjects & Training Regimen, Exercise Protocol & Dietary Intake & Main Results & Reference \\
\hline $\begin{array}{l}\text { Children and teenagers } \\
\mathrm{n}=267(178 / \mathrm{M}, 89 / \mathrm{F}) \\
\text { Age } 7-18 \mathrm{y}\end{array}$ & Self-reported physical activity & Type of diet reported as omnivore or vegetarian. & $\begin{array}{l}\text { Gut microbiota composition was affected by BMI, } \\
\text { exercise frequency, and diet type. Firmicutes were } \\
\text { significantly enriched in subjects with more } \\
\text { frequent exercise. }\end{array}$ & [38] \\
\hline $\begin{array}{l}\text { Overweight sedentary women } \\
\mathrm{n}=17 \\
\text { Age } 36.8 \pm 3.9 \mathrm{y} \\
\text { BMI } 31.8 \pm 4.4 \mathrm{~kg} / \mathrm{m}^{2}\end{array}$ & $\begin{array}{l}\text { Habitual physical activity. } \\
\text { Exercise intervention study: 6-week } \\
\text { control period without exercise, } \\
\text { 6-week programmed endurance } \\
\text { exercise, on a bicycle ergometer }\end{array}$ & $\begin{array}{l}\text { Habitual diet } \\
\text { Self-reported 3-day food record } \\
\text { No changes in intake of total energy, macronutrients or } \\
\text { fiber from baseline, after control or exercise period. } \\
\text { A modest increase in energy from starch }\end{array}$ & $\begin{array}{l}\text { Exercise did not affect } \alpha \text {-diversity. Exercise increased } \\
\text { Akkermansia spp. and reduced Proteobacteria } \\
\text { abundance. No significant changes in BMI or total fat } \\
\text { mass after exercise. Significant reduction in android } \\
\text { fat mass. }\end{array}$ & [16] \\
\hline $\begin{array}{l}\text { Healthy subjects } \\
\mathrm{n}=37(20 / \mathrm{M}, 17 / \mathrm{F}) \\
\text { Age } 25.7 \pm 2.2 \mathrm{y}\end{array}$ & $\mathrm{VO}_{2 \max }$ test to assess $\mathrm{CRF}$ & Habitual diet recorded for 7 days & $\begin{array}{l}\text { CRF correlated with Firmicutes/Bacteroidetes ratio. } \\
\text { No correlation between dietary factors or BMI and } \\
\text { Firmicutes/Bacteroidetes ratio. }\end{array}$ & [39] \\
\hline $\begin{array}{l}\text { Elderly community-dwelling } \\
\text { men } \\
\mathrm{n}=373 \\
\text { Age } 78-98 \text { y }\end{array}$ & $\begin{array}{l}\text { Habitual physical activity, measured } \\
\text { by activity sensor, for } 5 \text { days. Step } \\
\text { count as primary physical activity } \\
\text { variable }\end{array}$ & $\begin{array}{l}\text { Self-reported food intake (FFQ) } \\
\text { Step count was not associated with food or alcohol intake. }\end{array}$ & $\begin{array}{l}\text { Physical activity was not associated with } \alpha \text {-diversity } \\
\text { but was positively associated with } \beta \text {-diversity. } \\
\text { Increased physical activity was associated with greater } \\
\text { Faecalibacterium and Lachnospira spp. prevalence. }\end{array}$ & [40] \\
\hline $\begin{array}{l}\text { Elderly sedentary women } \\
\mathrm{n}=29 \\
\text { Age } 65-77 \text { y }\end{array}$ & $\begin{array}{l}\text { Exercise intervention study: } \\
\text { resistance training (trunk muscles) or } \\
\text { aerobic exercise (brisk walking) for } \\
12 \text { weeks }\end{array}$ & $\begin{array}{l}\text { Self-reported food intake (FFQ) } \\
\text { No changes in energy or nutrient intake after } \\
\text { interventions. }\end{array}$ & $\begin{array}{l}\text { Brisk walking increased the relative abundance of } \\
\text { Bacteroides spp. Bacteroides spp. abundance was } \\
\text { positively associated with improved CRF after aerobic } \\
\text { training but not with improved CRF after } \\
\text { resistance training. }\end{array}$ & [17] \\
\hline
\end{tabular}

BMI, body mass index; $y$, years; $F F Q$, food frequency questionnaire; $\mathrm{E} \%$, percentage of total energy intake; $\mathrm{SCFA}$, short-chain fatty acid; $\mathrm{M}_{\text {, males; }} \mathrm{F}$, females; $\mathrm{VO}_{2 \text { Peak }} / \mathrm{VO}_{2 \mathrm{Max}}$, maximum rate of oxygen consumption; CRF, cardiorespiratory fitness. 
Akkermansia sp. has been shown to inversely correlate with obesity [41] and Bacteroides spp. has been associated with a "Western" type of diet, with high protein and fat contents [42].

Differences between rugby players and sedentary controls were also detected in the microbial metabolism level, with increased amino acid and carbohydrate metabolism pathway activity detected in athletes [30]. Furthermore, higher fecal SCFA (acetate, propionate, and butyrate) levels were detected in rugby players compared with those in sedentary controls. SCFAs produced by gut bacteria have well-known health-promoting effects on the maintenance of intestinal barrier function, immune modulation, and the host's energy metabolism [43,44].

Similar to Clarke et al. [12], Petersen et al. [13] reported lower levels of Bacteroides spp. in competitive cyclists. Cyclists who trained $>11 \mathrm{~h} /$ week had a higher relative abundance of Prevotella spp. than those who trained less often. In addition, a meta-transcriptomics analysis showed that Prevotella transcripts were positively correlated with branched-chain amino acid (BCAA) metabolism pathways in the microbiome. BCAAs, especially leucine, are essential amino acids that promote muscle protein synthesis and may enhance recovery after exercise. Further, more fecal Methanobrevibacter smithii transcripts were identified in professional cyclists compared with amateur cyclists. M. smithii was associated with upregulated methane metabolism, which correlated positively with upregulation of SCFA metabolism pathways in the gut microbiome [13]. However, the authors recognized the lack of dietary control and the absence of a non-athlete control group in the study. In line with the results observed in cyclists, fecal microbiotas were classified into Prevotella- or Bacteroides-dominant enterotypes in a small group of elite race walkers [35].

Scheiman et al. [14] demonstrated that the relative abundance of Veillonella spp. bacteria among marathon runners was significantly higher after the marathon, compared with the pre-exercise abundance. In addition, the same research group conducted metagenomic analyses using fecal samples from ultramarathoners and Olympic level rowers, which revealed the enrichment of genes associated with lactate and propionate metabolism in post-exercise compared with pre-exercise samples. A follow-up study, conducted in mice, demonstrated that treatment with a Veillonella sp. strain, which was isolated from a marathon runner, increased the treadmill running time of mice by $13 \%$ [14].

The chronological impact of prolonged, very-high-intensity exercise on the gut microbial composition was investigated in four well-trained men who participated in a trans-oceanic rowing competition [34]. All, except one rower, who required antibiotic treatment before mid-race, showed increased microbial $\alpha$-diversity at mid-race, which continued until the end of the race. Baseline diversity was partially or completely restored three months after the competition. Although this study represents a very small sample size, the microbial metabolic pathways related to specific amino acids and medium and long-chain fatty acids tended to increase [34]. However, the diet differed considerably during the rowing race compared with the pre-race diet; therefore, dietary change may have also contributed to the microbial diversity findings.

In addition to the high-intense training that is practiced by professional or competitive athletes, exercise that is performed at the recommended minimum level, based on the World Health Organization (WHO) guidelines of 150 min of moderate-intensity exercise each week [45], appears to sufficiently modify the gut microbiota composition [37]. Premenopausal women who practiced continuous exercise at a low dose demonstrated increased abundance of Akkermansia muciniphila, Faecalibacterium prausnitzii, and Roseburia hominis, compared with those in sedentary women [37]. These all are bacterial species that are associated with health-promoting and anti-inflammatory effects [43]. Moreover, Faecalibacterium spp. and Roseburia spp. are among the most abundant butyrate-producers in the human gut [43,44]. Different dietary patterns between physically active and sedentary groups may have influenced the gut microbiota composition, as the intake of dietary fiber was significantly higher in active women compared with sedentary women (mean intake $30.9 \mathrm{~g}$ vs. $21.4 \mathrm{~g}$ ), and the intake of processed meat was significantly higher in the sedentary group [37]. 
Associations between physical activity levels and gut microbiota compositions have also been demonstrated in children [38] and seniors [40]. In a study cohort of children, aged 7-18 years, from the American Gut Project, BMI, exercise frequency, and type of diet were individually associated with the gut microbiota composition, after controlling for covariates (age, gender, and the use of antibiotics and probiotics) [38]. Exercise frequency was associated with gut microbiota enriched with Firmicutes phylum. Furthermore, children who exercised daily showed an increase in genera within Clostridiales, Lachnospiraceae, and Erysipelotrichaceae. In older men, physical activity, measured based on step count and self-reported activity, was not associated with microbial $\alpha$-diversity, but modest associations between physical activity level and Faecalibacterium spp. and Lachnospira spp. were found [40].

These studies indicated the existence of differences in the gut microbiota composition between athletes or physically active populations and sedentary populations. However, some of the characteristics of the microbiota composition in athletes and physically active people may be explained by diet, rather than the effects of exercise. Athletes often follow strict diets that support training and performance, and exercise extremes are often associated with dietary extremes [12]. Protein supplements are often consumed to meet the higher protein requirements of training individuals, although the popularity of protein supplements is likely also influenced by claims regarding increased muscle mass and improved performance and recovery [46]. Thus, protein intake can be substantially higher among athletes compared with the normal population. Following high protein intake, unabsorbed protein enters the colon and promotes the growth and selection of specific bacteria. Protein supplementation (whey isolate and beef hydrolysate) for 10 weeks increased the abundance of Bacteroidetes and decreased health-related taxa, including Roseburia spp., Blautia spp., and Bifidobacterium longum, in runners [32]. However, the long-term effects of such alterations in the gut microbiota composition on host health remain unclear.

Differences in dietary intake between study populations may explain some of the inconsistencies observed among the results of different studies. In a clinical study in Korea, total protein intake was inversely correlated with microbial diversity [33], whereas high protein intake was associated with increased microbial diversity among Irish professional rugby players [12]. Korean athletes did not meet the dietary recommendations for dietary fiber intake (recommendation $\geq 25 \mathrm{~g} /$ day; median intake in bodybuilders $19 \mathrm{~g} /$ day, endurance athletes $17 \mathrm{~g} /$ day), whereas Irish rugby players had fiber intake values at the recommended level (median intake $39 \mathrm{~g} /$ day). Undigested dietary fiber is an important energy and carbon source for the gut microbiota, acting as a substrate for SCFA synthesis, and representing a key contributor to microbial diversity. A high-protein diet, in combination with low-dietary-fiber diet, may be harmful for the gut microbiota composition, rather than high protein intake alone [47].

Limited data, derived primarily from animal studies, have suggested that popular sports nutrition supplements, such as caffeine, BCAAs, sodium bicarbonate, and carnitine, can modify the gut microbiota composition [48]. The effects of sports nutrition supplements on the gut microbiota remain understudied among athletes.

To summarize, exercise and training have been associated with compositional changes in the gut microbiota, including increased microbial diversity and increased abundance of health-promoting microbial species. Results from large study cohorts with recreationally active subjects suggest that exercise is associated with increases in genera within Clostridiales and Lachnospiraceae [38,40]. Although several studies have investigated small populations that likely lack sufficient statistical power, it is intriguing that they commonly identify genera such as Akkermansia [12,37] and Prevotella $[12,13]$ at higher abundance in athletes and physically active subjects. However, because the number of clinical studies remains limited, with highly different participant demographics and dietary intake-dietary fiber intake in specific - conclusions should be drawn carefully. Observational studies that have compared trained athletes and physically active subjects with sedentary subjects have suggested long-term effects of exercise training on gut microbiota composition, wherein the diet plays an important role. Sedentary and physically active subjects differ not only in their exercise patterns but also in 
their dietary intake and body composition, which are both factors that are associated with the gut microbiota composition.

\subsection{Impacts of Exercise Interventions on Gut Microbiota}

Because athletes often adhere to special diets that may influence the gut microbiota, exercise intervention studies can provide a more diet-independent approach for examining whether exercise has an impact on the host gut microbiota (Table 1). A research group demonstrated that exercise training intervention modified the gut microbiota composition of sedentary, non-trained, Finnish women, without changes in dietary habits, weight, or body composition [16]. The authors demonstrated that endurance exercise altered the gut microbiome of overweight, sedentary women, who participated in an exercise intervention that consisted of performing a bicycle ergometer routine, three times a week, for six weeks. The study showed no differences in total energy intake or the intake of macronutrients or dietary fiber after the training intervention. Differences were not found in the gut microbiota $\alpha$-diversity or phylum-level abundance between pre- and post-intervention samples; however, endurance exercise increased relative abundance of members of the genera Verrucomicrobia and Akkermansia and decreased the number of inflammation-associated Proteobacteria in the gut. Changes in Akkermansia spp. and genera and species within phyla Proteobacteria and Verrucomicrobia were responsive to exercise and were independent of age, weight, percent body fat, and food intake. Another study, performed by Morita et al. [17] found that a 12-week aerobic exercise training program significantly increased the relative abundance of Bacteroides spp. in elderly, sedentary women, without changes in nutrient intake.

A study by Allen et al. [15] supported these findings, showing that aerobic exercise induced changes in the gut microbiota composition, independent of dietary intake, among sedentary subjects; however, BMI may influence the response of gut microbiota to exercise. In their study, obese and lean individuals had different gut microbiota compositions at baseline, but after a 6-week aerobic exercise training program, no difference was found in microbiota community composition between obese and lean. In addition, aerobic exercise increased fecal SCFA concentrations and SCFA production capacity in lean subjects. The effects of exercise on gut microbiota were reversed after training was discontinued.

Overall, aerobic exercise training improves cardiorespiratory fitness (CRF), an effect that has been demonstrated in studies by Munukka et al. [16], Allen et al. [15] and Morita et al. [17]. CRF, which was measured as the maximum rate of oxygen consumption $\left(\mathrm{VO}_{2 \max }\right)$, has been observed to correlate with gut microbial diversity, fecal butyrate levels [36], and the Firmicutes-Bacteroidetes ratio [39]. The ratio between Firmicutes and Bacteroidetes phyla has been reported to be associated with body composition, with a higher fraction of Bacteroidetes associated with higher proportions of lean body mass, whereas lower levels have been associated with obesity [49].

In addition to human clinical studies, preclinical research in animal models has demonstrated that exercise changes the gut microbiota composition [50-55] and fecal SCFA concentrations, by increasing the production of butyrate $[50,54]$, in particular. However, forced exercise, under stressful conditions, such as the exhaustive swimming test, may impact gut microbiota differently than voluntary activity, such as wheel running. In an overtraining mouse model, the gut microbial diversity was reduced in mice forced to swim to exhaustion compared with that in non-swimming mice [56].

\subsection{Effects of Targeted Gut Microbiota Modulation on Physical Performance}

Due to nutritional, genetic, and environmental factors, dissecting the exact role played by gut microbiota on exercise performance in human clinical studies can be difficult. Germ-free animal models overcome many of those challenges and have been used to demonstrate the roles played by gut microbiota on physical performance outcomes. Hsu et al. [27] studied the swimming capacities of specific pathogen-free (SPF), germ-free (GF), and Bacteroides fragilis gnotobiotic mice. The swim-toexhaustion time was the shortest for GF mice and the longest for SPF mice, indicating decreased performance in the absence of gut microbiota. Similar findings regarding the reduced performance of GF mice compared with that in gnotobiotic and SPF mice were observed by Huang et al. [57]. 
In contrast to the above, Lahiri et al. [58] showed that GF mice and SPF mice did not differ in physical performance when exercising until exhaustion. However, GF mice demonstrated reduced muscle mass, fewer muscle fibers, and reduced muscle strength compared with SPF mice. Muscle atrophy in GF mice was associated with dysregulated mitochondrial biogenesis and reduced oxidative capacity. The transplantation of gut microbiota from SPF mice restored the muscle mass in GF mice, and treatment with a blend of SCFAs increased skeletal muscle mass and muscle strength in GF mice compared with those in untreated GF mice [58].

Antibiotic treatment drastically alters the composition of gut microbiota. Nay et al. [28] demonstrated that gut microbiota depletion, following a broad-spectrum antibiotic treatment, reduced the endurance running time of mice, and the endurance capacity was normalized after microbiota restoration through reseeding. Changes in endurance capacity were not related to changes in muscle mass, muscle fiber typology, or mitochondrial function but were associated with changes in muscle glycogen levels, which were restored after reseeding. Okamoto et al. [29] reported similar findings, in which the treadmill running time was shorter in mice treated with multiple antibiotics compared with that in non-treated controls. Okamoto et al. [29] also investigated the effects of SCFA production and its role on exercise performance, by feeding mice with fibers with differential substrate availability for microbial SCFA production in the gut. Mice fed with reduced fermentable fibers showed significantly shorter running times compared with mice fed with highly fermentable fibers, suggesting that microbiota and its substrates are both associated with physical performance. To further explore the putative role of SCFAs in performance capacity, antibiotic-treated mice were administered with a subcutaneous infusion of acetate or butyrate [29]. Acetate, but not butyrate, infusion improved the antibiotic-induced deterioration in running time.

Germ-free animals are of course an extreme model and may not explain the more subtle difference observed in the microbiota of humans. Nevertheless, studies in germ-free animal models have established a cause-effect relationship between gut microbiota and physical performance. Overall, the normalization of gut microbiota dysbiosis appeared to effectively restore exercise capacity and skeletal muscle parameters in rodents [58]. In addition, differences in gut microbiota compositions or the lack of gut microbiota have been shown to modulate exercise capacity, associated with muscle structure, muscle strength, and/or energy utilization [25,28]. Thus, the host appears to benefit from microbes through improved performance. The effects of gut microbiota are at least partially mediated by the production of SCFAs, which impact the gut and can also affect peripheral target tissues, via circulation.

\section{Probiotics as a Potential Ergogenic Aid to Enhance Physical Performance}

Nutritional ergogenic aids are dietary supplements that are consumed to help an individual exercise, enhance exercise performance capacity, enhance training adaptations, and improve recovery from exercise [59]. The use of nutritional ergogenic supplements is popular among athletes and recreationally active individuals of all age groups; however, evidence that supports the efficacy of many supplements is very limited or lacking. Performance-enhancing supplements with good or strong evidence have been identified by the International Olympic Committee and include the following: caffeine, creatine, nitrate, sodium bicarbonate, and beta-alanine [60]. Even when associated with only marginal improvements in performance, safe, proven, ergogenic dietary supplements may provide competitive benefits for an athlete.

Probiotic supplementation has been demonstrated to beneficially modify and support the gut microbiota composition [19-21]. Probiotics comprise many bacterial species, with the most studied probiotics belonging to the genera Lactobacillus (and associated genera) or Bifidobacterium. Associations between probiotics and physical performance and plausible mechanisms underlying these actions have been addressed in animal studies, which have suggested that probiotic supplementation protects against undesirable physiological changes that may be induced by strenuous exercise. Preclinical studies have demonstrated that probiotics can improve gut barrier properties [61] and the antioxidative status [62] 
and attenuate inflammatory response [63-65] in rodents after exhaustive exercise. However, how these protective effects are associated with physical performance outcomes has not been determined.

To date, the effects of probiotic supplementation have been studied in a variety of athletic and physically active populations, examining a variety of probiotic strains. Because the number of clinical studies on the association between probiotics and physical performance remains very low, with each study generally including a small number of participants and utilizing different exercise protocols, conclusions should be drawn carefully. The training status and training history of the participants can also influence the outcomes of exercise interventions [66]. Trained athletes and untrained individuals differ in their physiological responses to exercise [66], which can result in controversial results among different study populations. The use of resistance training programs alone during exercise intervention studies can contribute to changes in body composition and skeletal muscle organization that may supersede the impacts associated with probiotic supplementation, especially among previously sedentary populations.

The studies that have examined the effects of probiotics on physical performance have generally focused on mid- to long-term benefits, with supplementation periods varying from 2 weeks to 3 months (Table 2). The examined probiotic strains, formulas, and doses vary from study to study, which creates controversy among the obtained results. The most studied species are members of genera Lactobacillus (and associated genera) and Bifidobacterium; however, the benefits of probiotics, even within a single species, are often strain-specific. Furthermore, studies have been performed using both live and inactivated bacteria, which may have different modes of action. To comply with the definition, probiotics need to be alive microbes [18]. The proposed mode-of-action for probiotics and the benefits they provide to athletes are summarized in Figure 2.

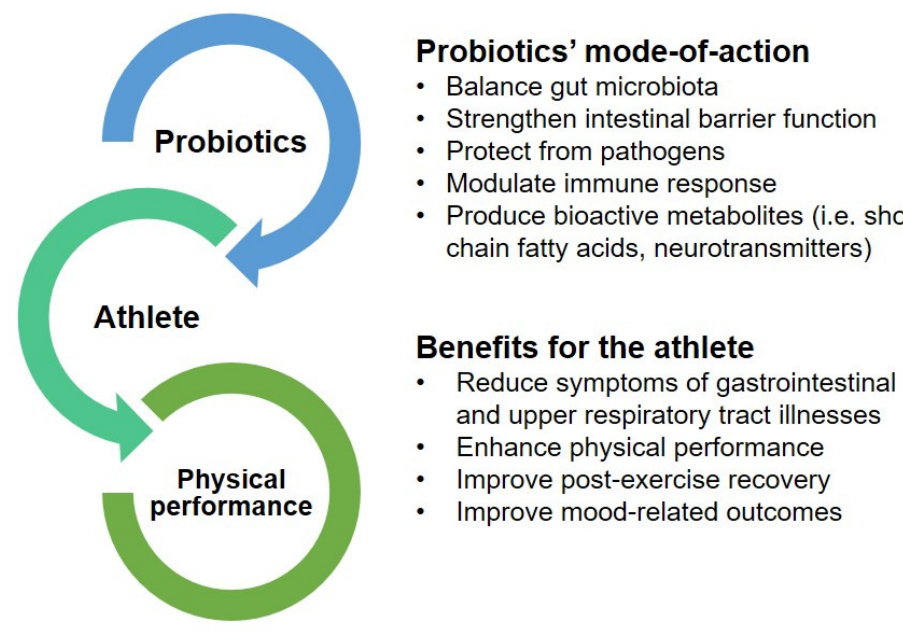

Figure 2. Proposed mechanisms and benefits of probiotic use in athletes.

\subsection{Reduction of Gastrointestinal and Upper Respiratory Tract Symptoms}

The beneficial effects of probiotics on GI health and upper respiratory tract (URT) illness symptoms among the general population have been well-acknowledged and reviewed extensively, elsewhere $[67,68]$. Because the exercise performance capacity of an athlete can be greatly influenced by overall health and resistance to infections, we have briefly highlighted the main findings, here.

Several studies have shown the potential of probiotic use to shorten the duration of GI disturbance episodes and relieve GI symptoms in athletes [69-74]. GI symptoms are common in athletes and can be influenced by the type of exercise performed [75]. GI challenges are most prominent in endurance athletes, among whom the prevalence of symptoms varies from $30 \%$ to up to $90 \%$, depending on the individual athlete and the type and the extremes of the exercise [75]. Typically, endurance athletes suffer from mild to severe symptoms, including nausea, vomiting, abdominal angina, and bloody diarrhea, which are caused, in part, by reduced blood circulation in the splanchnic region during 
intensive exercise [75]. Reduced circulation can result in oxygen deprivation in the gut epithelial cells, which damages the cells and causes changes in the gut permeability, a phenomenon known as "leaky gut syndrome." Metabolites, such as SCFAs, and other effector molecules, which are produced by beneficial bacteria, may improve the intestinal barrier function by increasing the expression of tight junction proteins in the epithelia, which reduces mucosal permeability [43]. Clinical results regarding the effects of probiotic administration on gut permeability in athletes are scarce and controversial, showing positive effects [72,73] or no effects [76,77].

Prolonged high-intensity exercise has been associated with transient immune dysfunction and increased illness risk [78]. Due to the transient suppression of mucosal and systemic immune responses, athletes are especially susceptible to viral respiratory infections, which affect the quality of training and physical performance $[79,80]$. In contrast, moderate exercise appears to protect against infections, whereas a sedentary lifestyle increases the risk $[78,79]$. Several studies have investigated whether probiotic supplementation can reduce the risks of respiratory tract illness episodes, alleviate symptoms, and reduce the duration of episodes among athletes and recreationally active subjects. The study results have not shown consistent effects for all of the aforementioned benefits; however, beneficial effects on incidence, duration, and the number of symptoms have been reported [69,81-85]. Consequently, the positive impacts of probiotic supplementation on URT symptoms and illness may facilitate an earlier return to normal activity levels, references $[83,85]$ increasing the hours spent on training, which can positively influence overall athletic performance. The administration of a two-strain probiotic supplement (Lactobacillus acidophilus NCFM and Bifidobacterium animalis subsp. lactis Bi-07) delayed the occurrence of URT illness and significantly increased the training load during a 5-month intervention period compared with placebo [83].

Reducing the incidence or severity of illness has positive impacts on performance during training and competition. Thus, probiotics may indirectly enhance physical performance.

\subsection{Enhancement of Physical Performance}

Depending on the sport and exercise type, physical performance can be measured as outcomes related to endurance, strength, speed, flexibility, or psychological performance (concentration, motivation) [86]. Exercise capacity often refers to exercise time to fatigue or exhaustion, at a given intensity or workload [87]. The potential for probiotics to improve physical performance has been recognized during exercise interventions and training studies involving athletes, recreational athletes, and sedentary individuals. Table 2 summarizes the studies examining the associations between physical performance and probiotic use, including preclinical and clinical studies, in which the used supplementation protocol fulfills the definition of a probiotic as a live organism.

Probiotic supplementation has been shown to increase the time to fatigue in both preclinical studies [88-90] and clinical studies, among both athletes and non-athletes [77,91,92]. Lactiplantibacillus plantarum TWK10 is among the most studied probiotic strains in terms of physical performance outcomes. A preclinical animal study demonstrated a dose-dependent increase in forelimb grip strength and endurance swimming time in mice supplemented with TWK10 [88]. Mice supplemented with TWK10 also showed an increased number of type I (slow-twitch) muscle fibers in the gastrocnemius muscle compared with control mice. These performance benefits were further confirmed in clinical studies. Endurance performance in an exhaustive treadmill exercise was improved in healthy, untrained adult males, who were supplemented daily with TWK10 for 6 weeks, compared with those who received a placebo [91]. In addition to significantly longer time to exhaustion (58\% longer running time in the probiotic vs. placebo groups), the post-exercise blood glucose level was higher in TWK10 group compared with the placebo group suggesting improved energy harvest from gluconeogenic precursors during exhaustive exercise. No significant improvements in perceived exertion during exhaustive exercise were reported by the probiotic supplementation group compared with the placebo group.

A more recent clinical study from the same research group demonstrated a dose-dependent improvement in endurance performance (time to exhaustion) following TWK10 supplementation 
$\left(3 \times 10^{10}\right.$ or $9 \times 10^{10}$ colony forming units, CFU, per day) in untrained subjects [92]. A higher dose of TWK10 significantly increased muscle mass compared with placebo treatment during the 6-week supplementation period. Further, blood lactate levels were significantly lower at the end of the exercise bout after both doses of probiotic supplementation compared with placebo treatment.

A double-blind, cross-over, exercise study examining trained male runners demonstrated that supplementation with a multi-strain probiotic (L. acidophilus, Lacticaseibacillus rhamnosus, Lacticaseibacillus casei, L. plantarum, Limosilactobacillus fermentum, Bifidobacterium lactis, B. breve, B. bifidum, and Streptococcus thermophilus) for 4 weeks significantly increased the time to fatigue on a treadmill running exercise performed in the heat compared with placebo, resulting in an average $16 \%$ longer running time [77]. No differences were observed in the severity of GI symptoms or GI permeability between the probiotic and placebo groups during exercise [77].

However, not all studies have shown enhancements in endurance performance following probiotic use in highly trained subjects or athletes $[81,84,85,93]$. Performance measurements related to exhaustive endurance exercise were not affected in endurance-trained males, after 4 weeks of L. fermentum VRI-003 supplementation [81], or in trained subjects, after Lactobacillus helveticus Lafti L10 [84]. A multi-species probiotic formulation (B. bifidum W23, B. lactis W51, Enterococcus faecium W54, L. acidophilus W22, Levilactobacillus brevis W63, and Lactococcus lactis W58) for 3 months did not have benefit in endurance performance in highly trained athletes [85]. In female swimmers, a multi-strain probiotic (L. acidophilus SPP, L. bulgaricus, B. bifidum, and S. thermophilus) yogurt improved the $\mathrm{VO}_{2 \max }$ (calculated using a Harvard step test) but had no impact on the 400-m swimming time after a 2-month intervention [82]. The 6-week supplementation with B. longum 35,624 in competitive, high-level, female swimmers did not enhance aerobic or anaerobic swimming performance or improve power or force production measurements [93]. Marshall et al. [94] found no effects for a 12-week multistrain probiotic or probiotic + glutamine supplementation protocol on the time to complete an ultra-marathon race compared with controls.

A few clinical studies have addressed the impacts of probiotic supplementation on sprint and power performance showing no clear benefits. Bacillus subtilis DE111 did not improve either strength or performance in male [95] or female athletes [96] when combined with a training protocol involving resistance exercises. Multi-strain probiotic supplementation for 12 weeks, combined with circuit-training, which involved resistance exercises, improved muscular performance to a similar degree as circuit-training alone in healthy, sedentary males [97], confirming the positive effects of resistance training on muscular outcomes, which is a result that has been demonstrated by other probiotic and exercise interventions among athletes $[95,96]$. The effects of probiotic supplementation on muscle strength and power production may be superseded by the effects of the resistance training protocols used by these studies. Regular resistance exercise strongly induces physiological changes in skeletal muscles and improves muscular strength in the long term

A recent trend in the field of gut microbiota and exercise research has been to isolate gut bacteria from the feces of elite athletes, to study the performance benefits of athlete-derived gut bacteria in animals. Recently, the oral administration of either B. longum subsp. longum OLP-01 [98] or Ligilactobacillus salivarius subsp. salicinius SA-03 [99], isolated from a female weightlifting Olympic medalist, was demonstrated to significantly increase forelimb grip strength and endurance capacity in a swim-to-exhaustion test in mice. Both OLP-01 and SA-03 significantly decreased blood lactate, ammonia, and CK levels after an acute exercise bout, and increased hepatic and muscle glycogen stores at autopsy and decreased which indicated improved energy utilization and the attenuation of fatigue-related biomarkers in mice. 
The inoculation of Veillonella atypica, isolated from a marathon runner, increased the treadmill running time in mice compared with that of control mice [14]. In a subsequent experiment, the intracolonic infusion of propionate also improved running times until exhaustion in mice. Veillonella species are known to metabolize lactate into propionate and acetate. Notably, a series of experiments by this research group also showed that ${ }^{13} \mathrm{C}_{3}$-lactate injected into the mouse tail vein could be found in the contents of colon and cecum, post-injection, indicating that circulating lactate can pass through the intestinal epithelium into the gut lumen. This seminal work in mice implies that lactate that is produced by skeletal muscles during prolonged anaerobic exercise may enter the colon from the circulation, which can serve as fuel for certain bacteria in the gut, providing a selection advantage [14]. These findings suggested that both the host and gut microbes may benefit from a symbiotic relationship; however, clinical evidence remains necessary to provide additional proof of these beneficial effects. Although athlete-originating microbes, such as Veillonella, sp. may show benefits in preclinical settings, the development of clinically proven commercial probiotics that can provide health benefits in humans requires further research.

Thus far, the number of human clinical studies investigating the impacts of probiotics on physical performance remains low, and those that have been performed have examined limited exercise types and performance measures. Clinical data have suggested that probiotics may improve the time to exhaustion during endurance exercise; however, these data are scarce and contradictory results exist. Studies have been conducted using a variety of probiotic strains that may differ in their efficacy. Further research remains necessary to determine the direct effects of probiotic supplementation on performance outcomes. 
Table 2. Probiotic studies on physical performance, post-exercise recovery and cognitive outcomes.

\begin{tabular}{|c|c|c|c|c|c|}
\hline Subjects & Design & Exercise Protocol and/or Intervention & Probiotic Supplementation & Main Results & Reference \\
\hline \multicolumn{6}{|l|}{ Animal studies: } \\
\hline $\begin{array}{l}\text { 6-week-old male ICR mice } \\
3 \text { groups } \\
n=8 / \text { group }\end{array}$ & Animal study & $\begin{array}{l}\text { Forelimb grip strength } \\
\text { Forced swim-to-exhaustion test, } \\
\text { with loads } \\
\text { 15-min swim test to determine recovery } \\
\text { and fatigue-related biomarkers }\end{array}$ & $\begin{array}{l}\text { L. plantarum TWK10 (LP10) } \\
\text { Dosing per group: } 0,2.05 \times 10^{8} \text {; or } \\
1.03 \times 10^{9} \mathrm{CFU} / \mathrm{kg} / \text { day for } 6 \text { weeks }\end{array}$ & $\begin{array}{l}\text { PRO improved forelimb grip strength and exhaustive } \\
\text { swimming time. Blood lactate, ammonia, and CK } \\
\text { levels were lower in PRO mice after a 15-min swim } \\
\text { compared with those in control mice. Type I muscle } \\
\text { fiber type increased, and relative muscle weight } \\
\text { increased in PRO mice vs. control mice. }\end{array}$ & [88] \\
\hline $\begin{array}{l}\text { 6-week-old male ICR mice } \\
4 \text { groups } \\
n=8 \text { /group }\end{array}$ & Animal study & $\begin{array}{l}\text { Forelimb grip strength } \\
\text { Forced swim-to-exhaustion test with } \\
\text { loads } \\
10 \text {-min and } 90 \text {-min swim tests, } \\
\text { to determine recovery and } \\
\text { fatigue-related biomarkers }\end{array}$ & $\begin{array}{l}\text { A kefir drink with L. fermentum } \\
\text { DSM 32,784 (LF26), L. helveticus } \\
\text { DSM 32,787 (LH43), L. paracasei } \\
\text { DSM 32,785 (LPC12), L. rhamnosus } \\
\text { DSM 32,786 (LRH10), and S. } \\
\text { thermophilus DSM 32,788 (ST30) } \\
\text { Kefir dosing per group: } 0,2.15,4.31 \text {, } \\
\text { or } 10.76 \mathrm{~g} / \mathrm{kg} / \text { day for } 4 \text { weeks }\end{array}$ & $\begin{array}{l}\text { Kefir supplementation increased time-to exhaustion, } \\
\text { and improved forelimb grip strength. } \\
\text { Blood lactate, ammonia, blood urea nitrogen, and CK } \\
\text { levels were lower after exercise in kefir-fed mice } \\
\text { compared with control mice, in a dose-dependent } \\
\text { manner. Glycogen contents in the liver and muscle } \\
\text { were higher in kefir-supplemented mice compared } \\
\text { with control mice. }\end{array}$ & [89] \\
\hline $\begin{array}{l}\text { 11-week-old male Wistar rats } \\
2 \text { groups } \\
n=13 \text { /group }\end{array}$ & Animal study & $\begin{array}{l}\text { Incremental speed exercise on a } \\
\text { treadmill, until exhaustion } \\
\text { Treadmill chamber, coupled with } \\
\text { gas-analyzer, to assess } \mathrm{VO}_{2 \max }\end{array}$ & $\begin{array}{l}\text { Saccharomyces boulardii (strain not } \\
\text { reported) } \\
3 \times 10^{8} \mathrm{CFU} / \mathrm{kg} / \text { day for } 10 \text { days }\end{array}$ & $\begin{array}{l}\text { PRO supplementation moderately improved aerobic } \\
\text { performance. PRO mice ran approx. } 8 \text { min longer } \\
\text { than control mice (until exhaustion) and had higher } \\
\text { maximal speed. }\end{array}$ & [90] \\
\hline $\begin{array}{l}\text { 7-week-old male ICR mice } \\
4 \text { groups } \\
\mathrm{n}=10 / \text { group }\end{array}$ & Animal study & $\begin{array}{l}\text { Forelimb grip strength } \\
\text { Forced swim-to-exhaustion test, } \\
\text { with loads } \\
10 \text {-min and } 90 \text {-min swim tests, } \\
\text { to determine recovery and } \\
\text { fatigue-related biomarkers }\end{array}$ & $\begin{array}{l}\text { B. longum subsp. longum OLP- } 01 \\
\text { isolated from a female weightlifter } \\
\text { Dosing per group: } 0,2.05 \times 10^{9}, \\
4.10 \times 10^{9}, \text { or } 1.03 \times 10^{10} \\
\text { CFU } / \mathrm{kg} / \text { day for } 4 \text { weeks }\end{array}$ & $\begin{array}{l}\text { PRO improved forelimb grip strength and } \\
\text { swim-to-exhaustion time, in a dose-dependent } \\
\text { manner. Blood lactate and ammonia levels were lower } \\
\text { after the acute swim test in PRO vs. control mice. } \\
\text { After a 90-min swim test, blood urea nitrogen and CK } \\
\text { levels were lower in PRO mice compared with those } \\
\text { in control mice. PRO increased hepatic and muscular } \\
\text { glycogen contents, observed at autopsy. }\end{array}$ & [98] \\
\hline $\begin{array}{l}\text { 6-week-old male ICR mice } \\
4 \text { groups } \\
n=10 / \text { group }\end{array}$ & Animal study & $\begin{array}{l}\text { Forelimb grip strength } \\
\text { Forced swim-to-exhaustion test, } \\
\text { with loads } \\
10 \text {-min and } 90 \text {-min swim tests, } \\
\text { to determine recovery and } \\
\text { fatigue-related biomarkers }\end{array}$ & $\begin{array}{l}\text { L. salivarius subsp. salicinius SA- } 03 \text {, } \\
\text { isolated from a female } \\
\text { weightlifter's gut microbiota } \\
\text { Dosing per group: } 0,2.05 \times 10^{9} \text {, } \\
4.10 \times 10^{9} \text {, or } 1.03 \times 10^{10} \\
\text { CFU } / \mathrm{kg} / \text { day for } 4 \text { weeks }\end{array}$ & $\begin{array}{l}\text { PRO improved forelimb grip strength and } \\
\text { swim-to-exhaustion time, in a dose-dependent } \\
\text { manner. Blood lactate and ammonia levels were lower } \\
\text { and blood glucose levels were higher after acute tests } \\
\text { in the PRO groups vs. control group. After a 90-min } \\
\text { swim, blood CK levels were lower in PRO groups } \\
\text { compared to the control group. PRO increased hepatic } \\
\text { and muscular glycogen contents, observed at autopsy. }\end{array}$ & [99] \\
\hline
\end{tabular}


Table 2. Cont.

\begin{tabular}{|c|c|c|c|c|c|}
\hline Subjects & Design & Exercise Protocol and/or Intervention & Probiotic Supplementation & Main Results & Reference \\
\hline \multicolumn{6}{|l|}{ Clinical studies: } \\
\hline \multicolumn{6}{|l|}{ Swimmers } \\
\hline $\begin{array}{l}\text { Highly trained competitive } \\
\text { swimmers } \\
\mathrm{n}=17 \text {, females } \\
\text { Age not reported }\end{array}$ & $\begin{array}{l}\text { Randomized, } \\
\text { double-blind, } \\
\text { placebo-controlled }\end{array}$ & $\begin{array}{l}6 \text { weeks of intensified off-season } \\
\text { training, including swimming and } \\
\text { resistance exercise. } \\
\text { Performance assessment: Vertical } \\
\text { jump force plate test, aerobic and } \\
\text { anaerobic swim performance test } \\
\text { Cognitive assessment: stress and } \\
\text { recovery during the intensified exercise } \\
\text { training load (the Recovery-Stress } \\
\text { Questionnaire for Athletes) }\end{array}$ & $\begin{array}{l}\text { B. longum } 35,624 ; \\
1 \times 10^{9} \mathrm{CFU} \text { bacteria/day for } \\
6 \text { weeks }\end{array}$ & $\begin{array}{l}\text { No significant differences in exercise performance or } \\
\text { systemic inflammation markers (at rest) between PRO } \\
\text { and PLA. } \\
\text { Differences in cognitive outcomes were detected } \\
\text { showing more favorable sport recovery related scores } \\
\text { in the PRO group. }\end{array}$ & [93] \\
\hline $\begin{array}{l}\text { Swimmers } \\
\mathrm{n}=46, \text { females } \\
\text { Age } 13.8 \pm 1.8 \mathrm{y}\end{array}$ & $\begin{array}{l}\text { Randomized, } \\
\text { placebo-controlled }\end{array}$ & $\begin{array}{l}\text { Normal exercise regimen } \\
\text { Performance assessment: } 400-\mathrm{m} \text { free- } \\
\text { swimming record, Harvard step test to, } \\
\text { measure } \mathrm{VO}_{2 \max }\end{array}$ & $\begin{array}{l}\text { L. acidophilus SPP, L. delbrueckii } \\
\text { subsp. bulgaricus, B. bifidum, } \\
\text { and S. salivarus subsp. } \\
\text { thermophilus, strains not reported } \\
400 \mathrm{~mL} \text { of probiotic yogurt/day } \\
\text { with } 4 \times 10^{10} \mathrm{CFU} / \mathrm{mL} \text { for } 8 \text { weeks }\end{array}$ & $\begin{array}{l}\text { Significant improvement in } \mathrm{VO}_{2 \max } \text { in the } \mathrm{PRO} \text { group. } \\
\text { No differences in } 400-\mathrm{m} \text { swimming times between } \\
\text { PRO and PLA groups. }\end{array}$ & [82] \\
\hline \multicolumn{6}{|l|}{ Endurance runners } \\
\hline $\begin{array}{l}\text { Elite distance runners } \\
\mathrm{n}=20, \text { males } \\
\text { Age } 27.3 \pm 6.4 \text { y }\end{array}$ & $\begin{array}{l}\text { Randomized, } \\
\text { double-blind, } \\
\text { placebo-controlled, } \\
\text { crossover }\end{array}$ & $\begin{array}{l}\text { Habitual winter-season training } \\
\text { Performance assessment: A treadmill } \\
\text { running test until exhaustion, at the } \\
\text { start of the study period and the end of } \\
\text { each study month }\end{array}$ & $\begin{array}{l}\text { L. fermentum VRI-003; } \\
1.2 \times 10^{10} \mathrm{CFU} \text { bacteria/day } \\
\text { for } 4 \text { weeks } \\
\text { Cross-over study, with 1-month } \\
\text { wash-out }\end{array}$ & $\begin{array}{l}\text { No difference in performance outcomes with PRO } \\
\text { compared to PLA. The number of illness days during } \\
\text { PRO supplementation was significantly lower than } \\
\text { with PLA ( } 30 \text { vs. } 72 \text { days). IFN- } \gamma \text { response was } \\
\text { moderately higher with the PRO than with PLA. }\end{array}$ & [81] \\
\hline $\begin{array}{l}\text { Endurance-trained runners } \\
\mathrm{n}=8 \text {, males } \\
\text { Age } 26 \pm 6 \text { y }\end{array}$ & $\begin{array}{l}\text { Randomized, blinded, } \\
\text { placebo-controlled, } \\
\text { cross-over }\end{array}$ & $\begin{array}{l}\text { Habitual training } \\
\text { Bout of exercise: } 2 \text {-h running exercise } \\
\text { at } 60 \% \mathrm{VO}_{2 \max } \text { in hot ambient } \\
\text { conditions }\end{array}$ & $\begin{array}{l}\text { L. casei (strain not reported) } \\
1 \times 10^{11} \mathrm{CFU} / \text { day for } 7 \text { days } \\
\text { Cross-over study, with } 1 \text {-month } \\
\text { wash-out }\end{array}$ & $\begin{array}{l}\text { No differences in hydration status between PRO and } \\
\text { PLA. Inflammatory cytokine levels were not different } \\
\text { between PRO and PLA, either pre-exercise or } \\
\text { post-exercise }(1,2,4 \text {, and } 24 \mathrm{~h} \text { after running). }\end{array}$ & {$[100]$} \\
\hline $\begin{array}{l}\text { Endurance-trained runners } \\
\mathrm{n}=8 \text {, males } \\
\text { Age } 26 \pm 6 \text { y }\end{array}$ & $\begin{array}{l}\text { Randomized, blinded, } \\
\text { placebo-controlled, } \\
\text { cross-over }\end{array}$ & $\begin{array}{l}\text { Habitual training } \\
\text { Bout of exercise: } 2 \text {-h running exercise, } \\
\text { at } 60 \% \mathrm{VO}_{2 \max } \text {, in hot, ambient } \\
\text { conditions }\end{array}$ & $\begin{array}{l}\text { L. casei (strain not reported) } \\
1 \times 10^{11} \mathrm{CFU} / \text { day for } 7 \text { days } \\
\text { Cross-over study with } 1 \text {-month } \\
\text { wash-out }\end{array}$ & $\begin{array}{l}\text { PRO and PLA did not differ in salivary anti-microbial } \\
\text { protein or serum cortisol responses during the } \\
\text { post-exercise period (1, 2, 4, and } 24 \mathrm{~h} \text { after running). }\end{array}$ & {$[101]$} \\
\hline $\begin{array}{l}\text { Runners } \\
\mathrm{n}=10 \text {, males } \\
\text { Age } 27 \pm 2 \mathrm{y}\end{array}$ & $\begin{array}{l}\text { Randomized, } \\
\text { double-blind, } \\
\text { placebo-controlled, } \\
\text { cross-over }\end{array}$ & $\begin{array}{l}\text { Normal training } \\
\text { Performance assessment: Running to } \\
\text { fatigue, at } 80 \% \text { of ventilatory threshold, } \\
\text { at } 35^{\circ} \mathrm{C} \text { and } 40 \% \text { humidity }\end{array}$ & $\begin{array}{l}\text { Multispecies probiotic, strains not } \\
\text { specified; L. acidophilus, } \\
\text { L. rhamnosus, L. casei, L. plantarum, } \\
\text { L. fermentum, B. lactis, B. breve, } \\
\text { B. bifidum, and S. thermophilus } \\
45 \times 10^{9} \text { CFU/day for } 4 \text { weeks, } \\
\text { cross-over study with a 3-week } \\
\text { wash-out }\end{array}$ & $\begin{array}{l}\text { PRO increased run time to fatigue (PRO 37:44 vs. } \\
\text { PLA 33:00 min:sec). A moderate, non-significant } \\
\text { reduction in pre-exercise and post-exercise serum } \\
\text { lipopolysaccharide (LPS) levels for PRO compared to } \\
\text { PLA. No difference between PRO and PLA in plasma } \\
\text { IL-6, IL-10, and IL-1Ra or GI permeability after } \\
\text { exercise in the heat. }\end{array}$ & {$[77]$} \\
\hline
\end{tabular}


Table 2. Cont.

\begin{tabular}{|c|c|c|c|c|c|}
\hline Subjects & Design & Exercise Protocol and/or Intervention & Probiotic Supplementation & Main Results & Reference \\
\hline $\begin{array}{l}\text { Marathon runners } \\
\mathrm{n}=42 \text {, males } \\
\text { Age } 39.5 \pm 9.4 \text { y }\end{array}$ & $\begin{array}{l}\text { Randomized, } \\
\text { double-blind, } \\
\text { placebo-controlled }\end{array}$ & $\begin{array}{l}\text { Usual training } \\
\text { Bout of exercise: marathon run }\end{array}$ & $\begin{array}{l}\text { L. casei Shirota } \\
40 \times 10^{9} \mathrm{CFU} / \text { day for } 30 \text { days }\end{array}$ & $\begin{array}{l}\text { PRO maintained salivary immune protection and } \\
\text { increased anti-inflammatory response on the upper } \\
\text { airways, immediately after the marathon. Serum } \\
\text { TNF- } \alpha \text { level was significantly lower immediately } \\
\text { post-marathon in the PRO group compared to that in } \\
\text { the PLA group }\end{array}$ & [102] \\
\hline $\begin{array}{l}\text { Marathon runners } \\
\mathrm{n}=119(105 / \mathrm{M}, 14 / \mathrm{F}) \\
\text { Average age } 40 \mathrm{y}\end{array}$ & $\begin{array}{l}\text { Randomized, } \\
\text { double-blind, } \\
\text { placebo-controlled }\end{array}$ & $\begin{array}{l}\text { 3-month training period, 6-day } \\
\text { preparation period } \\
\text { Bout of exercise: marathon run }\end{array}$ & $\begin{array}{l}\text { L. rhamnosus GG } \\
4.0 \times 10^{10} \text { bacteria in drink/day (or } \\
1 \times 10^{10} \text { in tablet/day) for } 3 \text { months }\end{array}$ & $\begin{array}{l}\text { PRO did not differ from PLA in ox-LDL or antioxidant } \\
\text { activity, pre- or post-marathon. }\end{array}$ & [103] \\
\hline $\begin{array}{l}\text { Marathon runners } \\
\mathrm{n}=24(20 / \mathrm{M}, 4 / \mathrm{F}) \\
\text { Age } 22-50 \text { y }\end{array}$ & $\begin{array}{l}\text { Randomized, } \\
\text { double-blind, } \\
\text { placebo- controlled, } \\
\text { matched-pairs }\end{array}$ & $\begin{array}{l}\text { Habitual training routine } \\
\text { Performance assessment/Bout of } \\
\text { exercise: Marathon race (no baseline } \\
\text { assessment) }\end{array}$ & $\begin{array}{l}\text { L. acidophilus CUL60, L. acidophilus } \\
\text { CUL21, B. bifidum CUL20, and B. } \\
\text { animalis subsp. lactis CUL } 34 \\
2.5 \times 10^{10} \text { CFU/day for } 28 \text { days }\end{array}$ & $\begin{array}{l}\text { No difference in marathon times between PRO and } \\
\text { PLA. During the final third of the race, the reduction } \\
\text { in average relative speed was greater in PLA } \\
\text { compared to PRO. GI symptoms were lower in PRO } \\
\text { compared to PLA during the final third. No difference } \\
\text { in post-race serum IL-6, IL-8, IL-10, and cortisol levels } \\
\text { between groups. }\end{array}$ & [104] \\
\hline $\begin{array}{l}\text { Ultramarathon runners } \\
\mathrm{n}=32(26 / \mathrm{M}, 6 / \mathrm{F}) \\
\text { Age } 23-53 \text { y }\end{array}$ & $\begin{array}{l}\text { Randomized, controlled } \\
\text { (single-blind for } \\
\text { glutamine } \\
\text { supplementation) }\end{array}$ & $\begin{array}{l}\text { Training for a marathon, } \\
\text { ultra-marathon race of } 294 \mathrm{~km} \\
\text { Performance assessment: } \\
\text { A graded exercise test, to maximal } \\
\text { exhaustion, on a motorized treadmill, } \\
\mathrm{VO}_{2 \text { max }} \text { test, pre-marathon, } \\
\text { time-to-completion in ultra- } \\
\text { marathon race }\end{array}$ & $\begin{array}{l}\text { PRO: Multi-strain probiotic, daily } \\
\text { dose } 30 \times 10^{9} \text { CFU comprising of } \\
10 \times 10^{9} \text { CFU L. acidophilus CUL-60 } \\
\text { (NCIMB } 30,157), 10 \times 10^{9} \text { CFU L. } \\
\text { acidophillus CUL-21 (NCIMB } \\
30,156), 9.5 \times 10^{9} \text { CFU B. bifidum } \\
\text { CUL-20 (NCIMB 30,172), } \\
\text { and } 0.5 \times 10^{9} \text { CFU B. animalis subsp. } \\
\text { lactis CUL-34 (NCIMB 30,153 + } \\
55.8 \text { g fructooligosaccharides } \\
\text { PRO + glutamine: } \\
\text { Daily dose } 2 \times 10^{9} \text { CFU L. } \\
\text { acidophilus CUL-60 (NCIMB 30,157), } \\
2 \times 10^{9} \text { CFU L. acidophilus CUL-21 } \\
\text { (NCIMB } 30156), 5 \times 10^{7} \text { CFU B. } \\
\text { bifidum CUL-20 (NCIMB 30,172), } \\
9.5 \times 10^{8} \text { CFU B. animalis subsp. } \\
\text { lactis CUL-34 (NCIMB } 30,153 \text { ), } \\
\text { and } 5 \times 10^{9} \text { CFU L. salivarius CUL61 } \\
\text { (NCIMB } 30,211 \text { ) } 0.9 \text { g glutamine } \\
12 \text { weeks before the marathon }\end{array}$ & $\begin{array}{l}\text { No difference in pre-race } \mathrm{VO}_{2 \max } \text { or in } \\
\text { time-to-completion for ultra-marathon between PRO, } \\
\text { PRO + glutamine, and control groups. } \\
\text { PRO and PRO + glutamine had no effects on immune } \\
\text { activation via extracellular heat-shock protein eHsp72 } \\
\text { signaling at post-race. }\end{array}$ & [94] \\
\hline
\end{tabular}


Table 2. Cont.

\begin{tabular}{|c|c|c|c|c|c|}
\hline Subjects & Design & Exercise Protocol and/or Intervention & Probiotic Supplementation & Main Results & Reference \\
\hline \multicolumn{6}{|l|}{ Cyclists, triathletes } \\
\hline $\begin{array}{l}\text { Competitive cyclists } \\
\mathrm{n}=99(64 / \mathrm{M}, 35 / \mathrm{F}) \\
\text { Age } 35 \pm 9 \mathrm{y} / \mathrm{M} \text { and } \\
36 \pm 9 \mathrm{y} / \mathrm{F}\end{array}$ & $\begin{array}{l}\text { Randomized, } \\
\text { double-blind, } \\
\text { placebo-controlled }\end{array}$ & $\begin{array}{l}\text { Habitual training (physical activity } \\
\text { recorded) } \\
\text { Performance assessment: an } \\
\text { incremental cycle ergometer } \\
\text { performance test (peak power output, } \\
\mathrm{VO}_{2 \max } \text { ) }\end{array}$ & $\begin{array}{l}\text { L. fermentum VRI-003 PC } \\
1 \times 10^{9} \mathrm{CFU} / \text { day for } 11 \text { weeks }\end{array}$ & $\begin{array}{l}\text { PRO did not affect training patterns or performance in } \\
\mathrm{VO}_{2 \text { max }} \text { testing. Acute exercise-induced changes in } \\
\text { anti- and pro-inflammatory cytokines were attenuated } \\
\text { with PRO. }\end{array}$ & [71] \\
\hline $\begin{array}{l}\text { Triathletes } \\
\text { Study I: } \mathrm{n}=18 \\
\text { Study II: } \mathrm{n}=16 \\
\text { Sex not reported } \\
\text { Age } 19-26 \text { y }\end{array}$ & $\begin{array}{l}\text { Randomized, } \\
\text { double-blind, } \\
\text { placebo-controlled }\end{array}$ & $\begin{array}{l}8 \text { weeks of programmed training } \\
\text { before a sprint triathlon (Study I) or } \\
\text { full triathlon competition (Study II) } \\
\text { Performance assessment: Wingate } \\
\text { and } 85 \% \mathrm{VO}_{2 \max } \text { test (after full } \\
\text { triathlon) }\end{array}$ & $\begin{array}{l}\text { L. plantarum PS128 } \\
3 \times 10^{10} \mathrm{CFU} / \text { day } \\
\text { Study I: last } 4 \text { weeks of training } \\
\text { Study II: last } 3 \text { weeks of training }\end{array}$ & $\begin{array}{l}\text { In Study II, performance during recovery from a full } \\
\text { triathlon was decreased in the PLA group and } \\
\text { maintained at the pre-triathlon level in the PRO group. } \\
\text { PRO group had lower blood TNF- } \alpha \text {, IFN- } \gamma \text {, IL-6, } \\
\text { and IL-8 levels compared to PLA, immediately after } \\
\text { exercise (Study I/II), with levels significantly lower in } \\
\text { PRO group } 3 \text { h after full triathlon (Study II). } \\
\text { Anti-inflammatory IL-10 was higher in the PRO } \\
\text { group, immediately after exercise (Study II) compared } \\
\text { with that in the PLA group. No differences in muscle } \\
\text { damage or fatigue markers detected between groups } \\
\text { (Study I/II) except, lower CK in PRO vs. PLA, } 3 \text { h after } \\
\text { full triathlon (Study II). Oxidative stress marker } \\
\text { (MPO) was lower in PRO after exercise, with no } \\
\text { differences } 3 \text { h post-exercise. }\end{array}$ & [105] \\
\hline $\begin{array}{l}\text { Elite athletes (badminton, } \\
\text { triathlon, cycling, alpinism, } \\
\text { karate, savate, kayak, judo, } \\
\text { tennis, and swimming) } \\
\mathrm{n}=50(36 / \mathrm{M}, 14 / \mathrm{F}) \\
\text { Age } 18-28 \mathrm{y}\end{array}$ & $\begin{array}{l}\text { Randomized, } \\
\text { double-blind, } \\
\text { placebo-controlled }\end{array}$ & $\begin{array}{l}\text { Habitual training }>11 \mathrm{~h} / \text { week, } \\
\text { self-reported training loads } \\
\text { Performance assessment: } \mathrm{VO}_{2 \max } \text {, by } \\
\text { a graded cardiopulmonary test, on a } \\
\text { treadmill } \\
\text { Cognitive assessment: Profile of } \\
\text { mood and state (POMS) questionnaire }\end{array}$ & $\begin{array}{l}\text { L. helveticus Lafti L10 } \\
2 \times 10^{10} \mathrm{CFU} / \text { day for } 14 \text { weeks }\end{array}$ & $\begin{array}{l}\text { No difference in } \mathrm{VO}_{2 \max } \text { and treadmill performance } \\
\text { between PRO and PLA. Increase in the subjective } \\
\text { feeling of vigor in the PRO group, but no difference in } \\
\text { other cognitive scores between groups. }\end{array}$ & [84] \\
\hline $\begin{array}{l}\text { Recreational triathletes } \\
\mathrm{n}=30(25 / \mathrm{M}, 5 / \mathrm{F}) \\
\text { Age } 35 \pm 1 \mathrm{y}\end{array}$ & $\begin{array}{l}\text { Randomized, } \\
\text { double-blind, } \\
\text { placebo-controlled }\end{array}$ & $\begin{array}{l}\text { Standardized training program for the } \\
\text { previous } 6 \text { months } \\
\text { Performance assessment/Bout of } \\
\text { exercise: a long-distance triathlon (no } \\
\text { baseline assessment) }\end{array}$ & $\begin{array}{l}\text { Multistrain probiotic, daily dose } \\
30 \times 10^{9} \mathrm{CFU}\left(10 \times 10^{9} \mathrm{CFU}\right. \\
\text { L. acidophilus CUL-60 (NCIMB } \\
30,157), 10 \times 10^{9} \mathrm{CFU} \text { L. acidophillus } \\
\text { CUL-21 (NCIMB 30,156), } 9.5 \times 10^{9} \\
\text { CFU B. bifidum CUL-20 (NCIMB } \\
30,172), 0.5 \times 10^{9} \mathrm{CFU} \text { B. animalis } \\
\text { subsp. lactis CUL-34 (NCIMB } \\
30,153))+55.8 \mathrm{~g} \\
\text { fructo-oligosaccharides, alone or in } \\
\text { combination with } 600 \mathrm{mg} N \text {-acetyl } \\
\text { carnitine }+400 \mathrm{mg} \alpha \text {-lipoic acid } \\
\text { for } 12 \text { weeks before and } \\
6 \text { days after triathlon }\end{array}$ & $\begin{array}{l}\text { Non-significantly faster times were reported for PRO } \\
\text { during swim and cycle stages, and a trend towards an } \\
\text { overall faster time was reported compared to PLA } \\
\text { ( } 86 \text { min faster). } \\
\text { No baseline measurements on performance } \\
\text { were assessed. } \\
\text { PRO reduced post-race plasma endotoxin levels, } \\
\text { whereas PLA had no effect. }\end{array}$ & [73] \\
\hline
\end{tabular}


Table 2. Cont.

\begin{tabular}{|c|c|c|c|c|c|}
\hline Subjects & Design & Exercise Protocol and/or Intervention & Probiotic Supplementation & Main Results & Reference \\
\hline \multicolumn{6}{|l|}{ Team sports } \\
\hline $\begin{array}{l}\text { Division I volleyball and } \\
\text { soccer athletes } \\
\mathrm{n}=23 \text {, females } \\
\text { Age } 19.6 \pm 1.0 \mathrm{y}\end{array}$ & $\begin{array}{l}\text { Randomized, } \\
\text { double-blind, } \\
\text { placebo-controlled }\end{array}$ & $\begin{array}{l}\text { Offseason resistance training protocol } \\
\text { Performance assessment: 1RM testing } \\
\text { (bench press, squat, deadlift), isometric } \\
\text { midthigh pull, vertical jump height, } \\
\text { pro-agility test }\end{array}$ & $\begin{array}{l}\text { Bacillus subtilis DE } 111 \\
5 \times 10^{9} \mathrm{CFU} / \text { day for } 10 \text { weeks }\end{array}$ & $\begin{array}{l}\text { PRO had no effect on strength or athletic performance } \\
\text { but significantly reduced percentage of body fat } \\
\text { percentage. }\end{array}$ & {$[96]$} \\
\hline $\begin{array}{l}\text { Division I baseball athletes } \\
\mathrm{n}=25, \text { males } \\
\text { Age } 20.1 \pm 1.5 \text { y }\end{array}$ & $\begin{array}{l}\text { Randomized, } \\
\text { double-blind, } \\
\text { placebo-controlled }\end{array}$ & $\begin{array}{l}\text { Resistance training program } \\
\text { Performance assessment: 1RM testing } \\
\text { (squat, deadlift), pro-agility test, } \\
\text { 10-yard sprint, standing long jump }\end{array}$ & $\begin{array}{l}\text { Bacillus subtilis DE111 } \\
1 \times 10^{9} \mathrm{CFU} / \text { day for } 12 \text { weeks }\end{array}$ & $\begin{array}{l}\text { No differences between PRO and PLA in strength, } \\
\text { performance, or body composition. PRO reduced } \\
\text { TNF- } \alpha \text { levels, but no differences in IL-10, cortisol, } \\
\text { zonulin, or testosterone levels observed between PRO } \\
\text { and PLA. }\end{array}$ & [95] \\
\hline $\begin{array}{l}\text { Highly trained athletes } \\
\mathrm{n}=29(13 / \mathrm{M}, 16 / \mathrm{F}) \\
\text { Age } 20-35 \text { years }\end{array}$ & $\begin{array}{l}\text { Randomized, } \\
\text { double-blind, } \\
\text { placebo-controlled }\end{array}$ & $\begin{array}{l}\text { Normal training } \\
\text { Performance assessment: Cycle } \\
\text { ergometer exercise test until exhaustion }\end{array}$ & $\begin{array}{l}\text { B. bifidum W23, B. lactis W51, } \\
\text { Enterococcus faecium W54, L. } \\
\text { acidophilus W22, L. brevis W63, } \\
\text { and L. lactis W58 } \\
1 \times 10^{10} \mathrm{CFU} / \text { day for } 12 \text { weeks }\end{array}$ & $\begin{array}{l}\text { No difference in performance between groups. } \\
\text { Weekly training loads were significantly higher in } \\
\text { PRO compared to PLA }(8.0 \pm 2.3 \text { vs. } 6.6 . \pm 4.3 \mathrm{~h} / \text { week }) \text {. } \\
\text { Exercise-induced reduction in tryptophan levels in } \\
\text { PLA but not in the PRO group. PRO reduced the } \\
\text { incidence of URT infections. }\end{array}$ & [85] \\
\hline \multicolumn{6}{|l|}{ Active non-athletes } \\
\hline $\begin{array}{l}\text { Resistance trained subjects } \\
\mathrm{n}=15, \text { males } \\
\text { Age } 25 \pm 4 \text { y }\end{array}$ & $\begin{array}{l}\text { Randomized, } \\
\text { double-blind, } \\
\text { placebo-controlled, } \\
\text { crossover }\end{array}$ & $\begin{array}{l}\text { Muscle-damaging eccentric exercise } \\
\text { bout } \\
\text { Performance assessment: isometric } \\
\text { peak torque, after muscle } \\
\text { damaging-exercise }\end{array}$ & $\begin{array}{l}\text { S. thermophilus FP4, and } \\
\text { B. breve BR03 } \\
5 \times 10^{9} \mathrm{CFU} \text { of each/day for } 21 \text { days }\end{array}$ & $\begin{array}{l}\text { PRO attenuated performance decrements caused by } \\
\text { muscle-damaging exercise during the recovery period. } \\
\text { No effects of PRO on muscle soreness, range of } \\
\text { motion, or plasma creatine kinase. PRO lowered } \\
\text { resting IL-6 concentrations that were sustained until } \\
48 \mathrm{~h} \text { post-exercise. }\end{array}$ & {$[106]$} \\
\hline $\begin{array}{l}\text { Recreational exercisers } \\
\mathrm{n}=29, \text { males } \\
\text { Age } 21.5 \pm 2.8 \text { y }\end{array}$ & $\begin{array}{l}\text { Single-blind, } \\
\text { crossover (casein first, } \\
\text { after washout, } \\
\text { PRO+casein) }\end{array}$ & $\begin{array}{l}\text { Single-leg exercise bout } \\
\text { Performance assessment: Anaerobic } \\
\text { power by modified Wingate test, } \\
\text { single-leg vertical jump, strength, by } \\
\text { 1RM testing in the one-legged leg press, } \\
\text { after muscle damaging-exercise }\end{array}$ & $\begin{array}{l}\text { Bacillus coagulans } \mathrm{BC} 30 \\
1 \times 10^{9} \mathrm{CFU} / \text { day }+20 \mathrm{~g} \text { casein for } \\
14 \text { days }\end{array}$ & $\begin{array}{l}\text { PRO + casein increased perceived recovery status and } \\
\text { reduced muscle soreness after exercise compared with } \\
\text { casein alone. } \\
\text { PRO + casein maintained post-exercise Wingate peak } \\
\text { power at the pre-exercise level, whereas casein alone } \\
\text { demonstrated reduced post-exercise performance. For } \\
1 \text { RM leg-press and vertical jump power, no differences } \\
\text { between groups in post-exercise performance. }\end{array}$ & {$[107]$} \\
\hline $\begin{array}{l}\text { Physically active subjects } \\
\mathrm{n}=27 \text {, females } \\
\text { Age } 18-25 \mathrm{y}\end{array}$ & Controlled, randomized & $\begin{array}{l}\text { Habitual moderate exercise } \\
\text { Performance assessment: treadmill } \\
\text { running until exhaustion, } \mathrm{VO}_{2 \max } \text { test } \\
\text { (Bruce test) }\end{array}$ & $\begin{array}{l}\text { Probiotic not specified } \\
450 \mathrm{~g} \text { of probiotic yogurt/day for } \\
2 \text { weeks }\end{array}$ & $\begin{array}{l}\text { No difference in } \mathrm{VO}_{2 \max } \text { between PRO and PLA. } \\
\text { PRO yogurt increased antioxidant enzyme activities } \\
\text { and reduced MMP2 and MMP9 levels before and after } \\
\text { exhaustive exercise. No significant differences } \\
\text { between PRO and PLA in high-sensitivity CRP, IL-6, } \\
\text { and TNF- } \alpha \text { after intense exercise. }\end{array}$ & [108] \\
\hline
\end{tabular}


Table 2. Cont

\begin{tabular}{|c|c|c|c|c|c|}
\hline Subjects & Design & Exercise Protocol and/or Intervention & Probiotic Supplementation & Main Results & Reference \\
\hline $\begin{array}{l}\text { Physically active students } \\
\mathrm{n}=11 \text {, sex not reported } \\
\text { Age } 22 \pm 1 \mathrm{y}\end{array}$ & Non-controlled & $\begin{array}{l}\text { Habitual training including endurance } \\
\text { exercise } \\
\text { Bout of exercise: } 2 \text {-h cycling at } 60 \% \text { of } \\
\mathrm{VO}_{2 \max }\end{array}$ & $\begin{array}{l}\text { L. acidophilus, L. delbrueckii subsp. } \\
\text { bulgaricus, Lactococcus lactis subsp. } \\
\text { lactis, L. casei, L. helveticus, L. } \\
\text { plantarum, L. rhamnosus, L. salivarius } \\
\text { subsp. salivarius, B. breve, B. bifidum, } \\
\text { B. infantis, B. longum, Bacillus } \\
\text { subtilis, S. thermophilus } \\
\text { minimum } 2 \times 10^{9} \text { CFU/capsule, } \\
3 \text { capsules/day } \\
\text { for } 30 \text { days }\end{array}$ & $\begin{array}{l}\text { Rating of perceived exertion during exercise was not } \\
\text { different between PRO and PLA. PRO did not affect } \\
\text { salivary antimicrobial proteins at rest or in response to } \\
\text { an acute bout of prolonged exercise. }\end{array}$ & [109] \\
\hline $\begin{array}{l}\text { Students } \\
\mathrm{n}=67, \text { males and females } \\
\text { ( } \mathrm{n} \text { not specified by sex) } \\
\text { Age 18-24 y }\end{array}$ & Controlled & $\begin{array}{l}\text { The exercise groups completed } \\
\text { structured, long-distance, endurance } \\
\text { run training, whereas the active group } \\
\text { maintained their usual exercise routine. } \\
\text { Performance assessment: } 1.5 \text {-mile } \\
(2.41 \mathrm{~km}) \text { walk or run }\end{array}$ & $\begin{array}{l}\text { Probiotic kefir, probiotic strain and } \\
\text { dose not specified } \\
15 \text { weeks }\end{array}$ & $\begin{array}{l}\text { No effect of PRO on 1.5-mile completion time. } \\
\text { PRO attenuated exercise-induced inflammation, } \\
\text { measured as serum CRP levels. }\end{array}$ & [110] \\
\hline $\begin{array}{l}\text { Students of physical } \\
\text { education } \\
\mathrm{n}=30 \text {, males } \\
\text { Average age: PRO } 21.56 \mathrm{y} \text {, } \\
\text { PLA } 21.28 \mathrm{y}\end{array}$ & $\begin{array}{l}\text { Randomized, matched } \\
\text { pairs }\end{array}$ & $\begin{array}{l}\text { Habitual training and training } \\
\text { program by the study } \\
\text { Performance assessment: Cooper test, } \\
\text { maximum aerobic power, using Bulk } \\
\text { test on a laboratory treadmill }\end{array}$ & $\begin{array}{l}\text { Probiotic strains unspecified, } \\
\text { included S. thermophilus and/or } \\
\text { L. delbrueckii subsp. bulgaricus } \\
1 \times 10^{5} \mathrm{CFU} / \mathrm{g} \text { in } 200 \mathrm{~mL} \\
\text { yogurt/day for } 10 \text { weeks }\end{array}$ & $\begin{array}{l}\mathrm{PRO} \text { improved } \mathrm{VO}_{2 \max } \text { and aerobic performance. } \\
\mathrm{PRO} \text { decreased serum high-sensitivity } \mathrm{CRP} \text { and } \\
\text { increased HDL levels. }\end{array}$ & [111] \\
\hline $\begin{array}{l}\text { Healthy participants } \\
\mathrm{n}=16 \text {, males } \\
\text { Age } 20-40 \text { y }\end{array}$ & $\begin{array}{l}\text { Randomized, } \\
\text { double-blind, } \\
\text { placebo-controlled }\end{array}$ & $\begin{array}{l}\text { Habitual exercise } \\
\text { Performance assessment: Treadmill } \\
\text { running at } 85 \% \mathrm{VO}_{2 \max } \text { workload, } \\
\text { until exhaustion. }\end{array}$ & $\begin{array}{l}\text { L. plantarum TWK10 } \\
1 \times 10^{11} \mathrm{CFU} / \text { day for } 6 \text { weeks }\end{array}$ & $\begin{array}{l}\text { PRO improved time-to-exhaustion (PLA vs. PRO: } \\
817 \pm 79 \text { s vs. } 1292 \pm 204 \text { s). Blood glucose was higher } \\
\text { in PRO vs. PLA after exhaustive exercise. No } \\
\text { differences in post-exercise blood lactate, free fatty } \\
\text { acid, CK levels between PRO and PLA. }\end{array}$ & [91] \\
\hline $\begin{array}{l}\text { Healthy participants } \\
\mathrm{n}=54,(27 / \mathrm{M}, 27 / \mathrm{F}) \\
\text { Age } 20-30 \mathrm{y}\end{array}$ & $\begin{array}{l}\text { Double-blind, } \\
\text { placebo-controlled }\end{array}$ & $\begin{array}{l}\text { Habitual exercise } \\
\text { Performance assessment: treadmill } \\
\text { running, at } 60 \% \mathrm{VO}_{2 \max } \text { and } 85 \% \\
\mathrm{VO}_{2 \max } \text { workload, until exhaustion }\end{array}$ & $\begin{array}{l}\text { L. plantarum TWK10 } \\
3 \times 10^{10} \mathrm{CFU} / \text { day or } \\
9 \times 10^{10} \mathrm{CFU} / \text { day for } 6 \text { weeks }\end{array}$ & $\begin{array}{l}\text { Exhaustion time was increased in both PRO groups } \\
\text { and were longer compared to PLA. Improvement in } \\
\text { exercise capacity was dose-dependent. PRO reduced } \\
\text { serum lactate during and after exercise compared to } \\
\text { PLA. Muscle mass increased in the high-dose } \\
\text { PRO group. }\end{array}$ & [92] \\
\hline $\begin{array}{l}\text { Healthy sedentary } \\
\text { individuals } \\
\mathrm{n}=41 \text {, males } \\
\text { Age } 19-26 \text { y }\end{array}$ & $\begin{array}{l}\text { Randomized, parallel, } \\
\text { placebo-controlled }\end{array}$ & $\begin{array}{l}\text { Circuit training protocol, including } \\
\text { resistance exercises, } 3 \text { times a week } \\
\text { Performance assessment: muscular } \\
\text { strength (peak torque) and power via } \\
\text { an isokinetic dynamometer }\end{array}$ & $\begin{array}{l}\text { L. acidophilus BCMC 12,130, L. casei } \\
\text { BCMC 12,313, L. lactis BCMC } \\
\text { 12,451, B. bifidum BCMC 02,290, B. } \\
\text { infantis BCMC 02,129 and B. longum } \\
\text { BCMC } 02,120 \\
6 \times 10^{10} \text { CFU/day for } 12 \text { weeks }\end{array}$ & $\begin{array}{l}\text { PRO did not show superior effects to PLA on } \\
\text { muscular strength (peak torque) and power. PRO } \\
\text { alone and exercise alone increased post-intervention } \\
\text { serum IL-10 concentrations from pre-intervention } \\
\text { levels. PRO and PLA with or without exercise, had no } \\
\text { effects on serum IL-6 concentration. }\end{array}$ & [97] \\
\hline
\end{tabular}


Table 2. Cont

\begin{tabular}{|c|c|c|c|c|c|}
\hline Subjects & Design & Exercise Protocol and/or Intervention & Probiotic Supplementation & Main Results & Reference \\
\hline $\begin{array}{l}\text { Healthy elderly individuals } \\
\text { with stretching experience } \\
\mathrm{n}=29(14 / \mathrm{M}, 25 / \mathrm{F}) \\
\text { Age }>65 \mathrm{y}\end{array}$ & $\begin{array}{l}\text { Randomized, } \\
\text { double-blind, } \\
\text { placebo-controlled }\end{array}$ & $\begin{array}{l}\text { Moderate resistance exercise training, } \\
\text { in instructed classes and at home } \\
\text { Cognitive assessment: General } \\
\text { cognitive performance (incl. tests for } \\
\text { accuracy, reaction time), mental state } \\
\text { (scoring for depression, anxiety, } \\
\text { and overall mental state) }\end{array}$ & $\begin{array}{l}\text { B. longum } \mathrm{BB} 536, \text { B. infantis } \mathrm{M}-63 \text {, } \\
\text { B. breve } \mathrm{M}-16 \mathrm{~V} \text { and } \mathrm{B} \text {. breve } \mathrm{B}-3 \\
5 \times 10^{10} \mathrm{CFU} / \text { day }\left(1.25 \times 10^{10} \mathrm{CFU}\right. \\
\text { each probiotic/day) for } 12 \text { weeks }\end{array}$ & $\begin{array}{l}\text { An increase in the general cognitive function scores } \\
\text { was observed in PRO and PLA groups, at } 12 \text { weeks. } \\
\text { PRO group showed a decrease in anxiety-depression } \\
\text { scores, body weight, BMI and body fat. }\end{array}$ & [112] \\
\hline
\end{tabular}

ICR mice, Institute of Cancer Research mice; L., Lactobacillus (or related genera); B., Bifidobacterium; S., Streptococcus; CFU, colony-forming units; PRO, probiotic supplementation; PLA,

placebo supplementation; $\mathrm{CK}$, creatine kinase; $\mathrm{VO}_{2}$ max , maximum rate of oxygen consumption; $\mathrm{M}$, males, F, females; IFN- $\gamma$, interferon $\gamma$; IL, interleukin; $\mathrm{GI}$, gastrointestinal; TNF- $\alpha=$ tumor necrosis factor $\alpha$; ox-LDL, oxidized low-density lipoprotein; MPO, myeloperoxidase; $1 \mathrm{RM}$, 1 repetition maximum; MMP2/9, matrix metalloproteinase 2/9; CRP, C-reactive protein; HDL, high-density lipoprotein; BMI, body mass index. 


\subsection{Improvement in Post-Exercise Recovery}

Recovery from exercise represents an important determinant of performance enhancement that enables adaptation to training. Strategies for optimizing recovery may prevent under-recovery, overtraining syndrome, injuries, or illnesses [86]. Exercise-induced muscle damage, inflammation, metabolic responses, and fatigue are part of the recovery process and are, therefore, important contributors to training adaptation. In addition to physical performance outcomes, biochemical markers and the athlete's subjective perception of fatigue and readiness to perform can be assessed, to evaluate the subject's recovery state after exercise.

The impacts of probiotic supplementation on health outcomes, performance measurements, and/or biochemical markers in athletes have been addressed in numerous studies, comparing post-intervention and pre-intervention resting levels after a training period. Endpoints and markers that are measured directly after acute exercise sessions and during recovery periods provide a more defined approach to the evaluation of post-exercise recovery status. The effects of probiotics on biochemical and immune markers during the post-exercise recovery state after an exercise session have been reported in several studies (Table 2). The effects of probiotic supplementation on performance capacity during the recovery period after exercise were studied in triathletes by Huang et al. [105], who assessed anaerobic (Wingate test) and aerobic ( $85 \% \mathrm{VO}_{2 \max }$ test) exercise capacities, 48 and $72 \mathrm{~h}$ after a triathlon race. Probiotic supplementation (L. plantarum PS128) for 3 weeks significantly improved maximal power, the fatigue index, and endurance indices during the recovery period after the triathlon race compared with those in the placebo group. The probiotic group also maintained aerobic performance, when measured during the recovery period at the resting level, whereas the placebo group reached exhaustion significantly sooner during the recovery period

High-intensity training acutely increases muscle damage, fatigue, and soreness, which contributed to decreased athletic performance. Excess mechanical load creates micro-damage to skeletal muscle tissues, causing local inflammation and decreasing muscle function. Inflammation that occurs in the muscle tissue is a mechanism of muscular adaptation to exercise, through which the muscle can regenerate and repair itself [113]. Mechanical overload has been associated with increased systemic levels of muscle-derived proteins, such as creatine kinase (CK) and myoglobin [107]. Interleukin (IL)-6 is a cytokine that is produced by contracting muscles during exercise and increases in the plasma after strenuous exercise. Changes in muscle-damage-related biomarkers are associated with delayed-onset muscle soreness (DOMS) and muscle recovery [114].

In athletes who participated in a full triathlon championship competition, the L. plantarum PS128 probiotic group and the placebo group did not differ in blood CK values immediately after competition [105]. However, in the probiotic group, the CK level was significantly lower $3 \mathrm{~h}$ post-exercise compared with that in the placebo group. No differences in post-exercise lactate dehydrogenase, myoglobin, or free fatty acids were observed between the probiotic and placebo groups. After less-demanding sprint triathlon, supplementation with L. plantarum PS128 had no effects compared with placebo on post-exercise CK or blood lactate measurements [105]. In sedentary subjects who participated in exhaustive exercise, L. plantarum TWK10 improved blood lactate clearance during a 1-h post-exercise recovery period [92]. Blood lactate and lactate clearance are often measured to assess recovery. However, the suitability of these variables to evaluate fatigue and recovery is controversial and not agreed on [86].

In the triathlete study performed by Huang et al. [105], the levels of exercise-induced serum pro-inflammatory cytokines, tumor necrosis factor (TNF)- $\alpha$, interferon (IFN)- $\gamma$, IL-6, and IL-8, were significantly lower in the probiotic group compared with those in the placebo group, both immediately and $3 \mathrm{~h}$ after the triathlon competition. The investigators also found increased anti-inflammatory IL-10 levels after the exercise, but not at the 3-h time point. Prolonged, high-intensity exercise is well-known to be associated with transient inflammation, immune dysfunction, and oxidative stress [78]. Lamprecht et al. [72] and Mazani et al. [108] both demonstrated a trend towards reduced circulating TNF- $\alpha$ levels in the probiotic group compared with the placebo, immediately after exhaustive 
exercise, supporting the findings reported by Huang et al. [105]. Probiotic interventions were found to increase antioxidant capacity [108], reduce oxidated molecules [72], and decrease myeloperoxidase and increase thioredoxin activity [105], suggesting overall benefits associated with reduced exercise-induced oxidative stress levels. However, some probiotic intervention studies have not found any effects on inflammation $[93,100,101,104]$; thus, further investigations are warranted to understand the effects of probiotics on post-exercise immune function and inflammation.

Increased levels of inflammatory cytokines may result from damaged muscle tissue but may also be caused by the disruption of intestinal barrier function after prolonged, intense, endurance exercise. Reduced intestinal blood flow causes the acute disruption of epithelial barrier function and increased leakage, resulting in endotoxemia, during which microbial lipopolysaccharides enter the blood circulation. The resulting systemic inflammation compromises the athlete's ability to recover and perform. Lamprecht et al. [72] showed that a 14-week, multi-strain, probiotic supplementation protocol reduced fecal zonulin and TNF- $\alpha$ levels significantly compared with those supplemented with placebo, indicating improved intestinal barrier integrity and reduced systemic inflammation, respectively. Probiotic supplementation of shorter duration for 4 weeks resulted in reduced gastrointestinal permeability and improved exercise capacity under heat conditions, with no impacts on circulating cytokine levels [77]. Moreover, probiotic supplementation did not attenuate exertional heat stress-induced blood endotoxemia or inflammation [100], the salivary antimicrobial protein response [101], or extracellular heat shock protein 72 (eHsp72) concentrations [94], when monitored during the recovery stage, post-exercise. Under normal ambient conditions, a 30-day supplementation protocol using a multi-strain probiotic did not demonstrate differences in the salivary antimicrobial peptides during post-exercise recovery after $2 \mathrm{~h}$ of cycling at $60 \%$ of $\mathrm{VO}_{2 \max }$ [109].

The benefits of probiotic use during recovery from muscle-damaging exercise have been demonstrated in two clinical studies $[106,107]$. A study performed in resistance-trained men, demonstrated that a 3-week supplementation with S. thermophilus FP4 and B. breve BR03 moderately attenuated post-exercise decreases in muscle performance, as assessed by isometric average peak torque, 24 to $72 \mathrm{~h}$ after a muscle-damaging exercise [106]. In addition, circulating IL-6 concentrations were reduced after the 3-week probiotic supplementation protocol but were not affected by the treatment during the post-exercise recovery period. Beneficial effects were observed in the resting arm angle after probiotic supplementation, whereas no differences in flexed arm angle, CK levels, or muscle soreness were observed during the recovery period, between the probiotic and placebo groups.

A 2-week supplementation of casein combined with Bacillus coagulans BC30, increased perceived recovery status scores at 24 and $72 \mathrm{~h}$ after muscle-damaging exercise compared with casein supplementation alone in recreationally trained men [107]. Probiotic combined with casein also reduced perceived muscle soreness compared with casein alone, $72 \mathrm{~h}$ post-exercise. Trends toward reduced circulating CK levels and improved performance, as measured by the Wingate test, were observed after the muscle-damaging exercise following probiotics combined with casein supplementation compared with casein supplementation alone. The amounts of muscle swelling and blood urea nitrogen levels did not differ between the groups. The effects of $B$. coagulans BC 30 have also been studied among soldiers, who are known to train intensively, on a daily basis, with limited time to recover. $\beta$-Hydroxy- $\beta$-methylbutyrate calcium (CaHMB) combined with BC30 maintained muscle integrity during an intensive 40-day military training period better than CaHMB alone [115]. Treatment with both CaHMB combined with BC30 and CaHMB alone significantly attenuated resting serum IL-1 $\beta$, IL-2, and TNF- $\alpha$ concentrations after the 40-day supplementation period, whereas CaHMB that was combined with BC30 significantly reduced serum IL-6 and IL-10 during the post-intervention period compared with control. However, the acute effects on biochemical marker levels during the recovery state were not evaluated. Probiotics have been proposed to enhance recovery and to shorten the time necessary for muscle repair by improving the absorption and utilization of dietary nutrients $[107,115,116]$. 
To date, studies that have assessed performance and exercise capacity during the post-exercise recovery period remain low in number. Studies that have investigated the probiotic effects on biochemical and immune markers during the post-exercise recovery period have shown somewhat controversial results, due to large variations in study designs, training protocols, analytical methods, athletic populations, and investigated probiotic strains. These results also warrant longer follow-up measurements during the recovery period. Thus, conclusions cannot be drawn regarding probiotics' potential to improve recovery and attenuate exercise-induced physiological responses, which are, in part, necessary for training adaptations and performance enhancement. Furthermore, the relationships between physiological recovery processes and improvements in performance should be established more clearly before further conclusions can be made regarding the ergogenic potential of probiotics.

\subsection{Improvements in Mood-Related Outcomes}

Good physical condition, accompanied by good mental condition, are part of a continuum that enables the optimal training and performance of competitive athletes. Fatigue and mood disturbances during performance are common among athletes during the training season and in competition [4]. Intensive exercise causes both physical and psychological stress responses, which can often be difficult to differentiate between.

Results from preclinical and clinical studies suggest that probiotic administration may have positive effects in mental responses $[117,118]$. Few studies have investigated the effects of probiotic supplementation on the cognitive outcomes of athletes or physically active subjects $[84,93,112]$ (Table 2 ). In a group of highly trained, elite athletes, the self-rated sense of vigor (Profile of Mood States, POMS questionnaire) was significantly increased among the probiotic group, who ingested L. helveticus Lafti for 14 weeks, compared with the placebo group, with no difference in the total mood disturbance scores between groups detected [84]. Decreased vigor is related to an individual's feelings of possessing the necessary physical strength to perform.

In a study involving highly trained, female, competitive swimmers, probiotic supplementation (B. longum 35,624) during a 6-week intensive training period improved the cognitive functions of the athletes [93]. At the end of the intensive training period, significant differences in the scores related to sport recovery categories (the Recovery-Stress Questionnaire for Athletes) were detected between groups, showing that the scores of the probiotic group were more favorable compared with those in the placebo group. A training intervention performed in healthy, elderly, Japanese individuals demonstrated that a 12-week resistance training program induced beneficial effects on the general cognitive functions of both the placebo and probiotic groups [112]. The 12-week supplementation with multi-strain bifidobacteria significantly decreased overall mental state scores compared with baseline scores, with lower scores indicating lower depression and anxiety symptoms [112].

Probiotics are, by definition, live microorganisms. In addition to viable bacteria, studies have been performed using inactivated bacteria. Two studies have investigated the effects of supplementation with inactivated Lactobacillus on mood related measurements [119,120]. A 4-week supplementation period, using heat-inactivated L. gasseri OLL2809, reduced tension-anxiety scores after a 1-h cycle ergometer exercise, compared with baseline scores [119]. The 12-week administration of heat-inactivated L. gasseri CP2305 significantly decreased scores that measured physical fatigue, anxiety, and depression in male university student-athletes [120]. Salivary cortisol and chromogranin A serve as biochemical markers for stress. In the above-mentioned studies, salivary chromogranin A was significantly reduced in the inactivated Lactobacillus group compared with that in the placebo group [120], whereas no changes in salivary cortisol levels were detected after the intervention period $[119,120]$. 
Probiotics appear to have benefits on cognitive outcomes in athletes, as measured by self-reported scores. Several potential mechanisms exist for the gut bacteria to interact with the brain, through the gut-brain axis. Messages to the brain can be delivered by gut-derived cytokines, hormones, and bacterial metabolites, including neurotransmitters, or via the vagus nerve [4]. Probiotic studies that focus on the mental health of athletes represent an emerging area in the field of sports nutrition and exercise performance. The number of probiotic studies remains very low, with studies often including a low number of subjects, and a wide variety of questionnaires have been used to assess cognitive outcomes. Despite limited evidence, cognitive health remains an intriguing area of sports nutrition research.

\section{Conclusions}

Overall, growing evidence from animal and human studies has indicated that the gut microbiota composition plays an important role in host physiology and can affect physical performance. The microbial community of the gut and its potential health benefits are highly impacted by individual life choices, including dietary patterns and activity levels. Probiotics are known for their potential to reduce GI and URT symptoms and infection episodes and thus may benefit the athlete by increasing the numbers of healthy training days and completed races. Further, probiotics may support athletic performance by enhancing training adaptations, attenuating physiological responses during post-exercise recovery periods, and improving mood and mental responses after intense exercise. Therefore, probiotics can be considered to act as indirect ergogenic aids; however, the causal impacts of indirect effects on performance remain to be established in good-quality, long-term studies of adequate size that consider the diet, and the training and competition seasons of the athletes. The functions of probiotics in enhancing performance, as direct ergogenic aids, require additional research that targets the mode of action that underlies their potential benefits.

Author Contributions: Conceptualization, M.M., R.A.-J., A.L., and M.J.L.; writing—original draft preparation, M.M. and R.A.-J.; writing-review and editing, M.M., R.A.-J., A.L., and M.J.L.; visualization, M.M. and R.A.-J. All authors have read and agreed to the published version of the manuscript.

Funding: This research received no external funding.

Acknowledgments: Arthur Ouwehand and Johanna Maukonen are acknowledged for their comments during the manuscript preparation.

Conflicts of Interest: The authors are employees of Danisco Sweeteners Oy, legal entity of DuPont Nutrition \& Biosciences that manufactures probiotics.

\section{References}

1. Sender, R.; Fuchs, S.; Milo, R. Revised Estimates for the Number of Human and Bacteria Cells in the Body. PLoS Biol. 2016, 14, e1002533. [CrossRef] [PubMed]

2. Cheng, H.Y.; Ning, M.X.; Chen, D.K.; Ma, W.T. Interactions Between the Gut Microbiota and the Host Innate Immune Response Against Pathogens. Front. Immunol. 2019, 10, 607. [CrossRef] [PubMed]

3. Dinan, T.G.; Cryan, J.F. Regulation of the stress response by the gut microbiota: Implications for psychoneuroendocrinology. Psychoneuroendocrinology 2012, 37, 1369-1378. [CrossRef] [PubMed]

4. Clark, A.; Mach, N. Exercise-induced stress behavior, gut-microbiota-brain axis and diet: A systematic review for athletes. J. Int. Soc. Sports Nutr. 2016, 13, 43. [CrossRef]

5. Larsen, O.F.; Claassen, E. The mechanistic link between health and gut microbiota diversity. Sci. Rep. 2018, 8, 1-5. [CrossRef]

6. Neish, A.S.J.G. Microbes in gastrointestinal health and disease. Gastroenterology 2009, 136, 65-80. [CrossRef]

7. Lozupone, C.A.; Stombaugh, J.I.; Gordon, J.I.; Jansson, J.K.; Knight, R.J.N. Diversity, stability and resilience of the human gut microbiota. Nature 2012, 489, 220-230. [CrossRef]

8. Valdes, A.M.; Walter, J.; Segal, E.; Spector, T.D. Role of the gut microbiota in nutrition and health. BMJ 2018, 361, k2179. [CrossRef] 
9. Dinan, T.G.; Cryan, J.F. The microbiome-gut-brain axis in health and disease. Gastroenterol. Clin. N. Am. 2017, 46, 77-89. [CrossRef]

10. Grosicki, G.J.; Fielding, R.A.; Lustgarten, M.S. Gut microbiota contribute to age-related changes in skeletal muscle size, composition, and function: Biological basis for a gut-muscle axis. Calcif. Tissue Int. 2018, 102, 433-442. [CrossRef]

11. McKinney, J.; Lithwick, D.J.; Morrison, B.N.; Nazzari, H.; Isserow, S.H.; Heilbron, B.; Krahn, A.D. The health benefits of physical activity and cardiorespiratory fitness. Br. Columbia Med. J. 2016, 58, 131-137.

12. Clarke, S.F.; Murphy, E.F.; O’Sullivan, O.; Lucey, A.J.; Humphreys, M.; Hogan, A.; Hayes, P.; O’Reilly, M.; Jeffery, I.B.; Wood-Martin, R.; et al. Exercise and associated dietary extremes impact on gut microbial diversity. Gut 2014, 63, 1913-1920. [CrossRef] [PubMed]

13. Petersen, L.M.; Bautista, E.J.; Nguyen, H.; Hanson, B.M.; Chen, L.; Lek, S.H.; Sodergren, E.; Weinstock, G.M. Community characteristics of the gut microbiomes of competitive cyclists. Microbiome 2017, 5, 98. [CrossRef] [PubMed]

14. Scheiman, J.; Luber, J.M.; Chavkin, T.A.; MacDonald, T.; Tung, A.; Pham, L.-D.; Wibowo, M.C.; Wurth, R.C.; Punthambaker, S.; Tierney, B.T.; et al. Meta-omics analysis of elite athletes identifies a performance-enhancing microbe that functions via lactate metabolism. Nat. Med. 2019, 25, 1104-1109. [CrossRef]

15. Allen, J.M.; Mailing, L.J.; Niemiro, G.M.; Moore, R.; Cook, M.D.; White, B.A.; Holscher, H.D.; Woods, J.A. Exercise Alters Gut Microbiota Composition and Function in Lean and Obese Humans. Med. Sci. Sports Exerc. 2018, 50, 747-757. [CrossRef]

16. Munukka, E.; Ahtiainen, J.P.; Puigbo, P.; Jalkanen, S.; Pahkala, K.; Keskitalo, A.; Kujala, U.M.; Pietila, S.; Hollmen, M.; Elo, L.; et al. Six-Week Endurance Exercise Alters Gut Metagenome That Is not Reflected in Systemic Metabolism in Over-weight Women. Front. Microbiol. 2018, 9, 2323. [CrossRef]

17. Morita, E.; Yokoyama, H.; Imai, D.; Takeda, R.; Ota, A.; Kawai, E.; Hisada, T.; Emoto, M.; Suzuki, Y.; Okazaki, K. Aerobic exercise training with Brisk walking increases intestinal Bacteroides in healthy elderly women. Nutrients 2019, 11, 868. [CrossRef]

18. Hill, C.; Guarner, F.; Reid, G.; Gibson, G.R.; Merenstein, D.J.; Pot, B.; Morelli, L.; Canani, R.B.; Flint, H.J.; Salminen, S. The International Scientific Association for Probiotics and Prebiotics consensus statement on the scope and appropriate use of the term probiotic. Nat. Rev. Gastroenterol. Hepatol. 2014, 11, 506-514. [CrossRef]

19. Sánchez, B.; Delgado, S.; Blanco-Míguez, A.; Lourenço, A.; Gueimonde, M.; Margolles, A. Probiotics, gut microbiota, and their influence on host health and disease. Mol. Nutr. Food Res. 2017, 61, 1600240. [CrossRef]

20. Korpela, K.; Salonen, A.; Vepsäläinen, O.; Suomalainen, M.; Kolmeder, C.; Varjosalo, M.; Miettinen, S.; Kukkonen, K.; Savilahti, E.; Kuitunen, M. Probiotic supplementation restores normal microbiota composition and function in antibiotic-treated and in caesarean-born infants. Microbiome 2018, 6, 1-11. [CrossRef]

21. Hibberd, A.; Yde, C.; Ziegler, M.; Honoré, A.H.; Saarinen, M.T.; Lahtinen, S.; Stahl, B.; Jensen, H.; Stenman, L. Probiotic or synbiotic alters the gut microbiota and metabolism in a randomised controlled trial of weight management in overweight adults. Benef. Microbes 2019, 10, 121-135. [CrossRef] [PubMed]

22. Eutamene, H.; Bueno, L. Role of probiotics in correcting abnormalities of colonic flora induced by stress. Gut 2007, 56, 1495-1497. [CrossRef] [PubMed]

23. Kim, N.; Yun, M.; Oh, Y.J.; Choi, H.-J. Mind-altering with the gut: Modulation of the gut-brain axis with probiotics. J. Microbiol. 2018, 56, 172-182. [CrossRef] [PubMed]

24. Jäger, R.; Mohr, A.E.; Carpenter, K.C.; Kerksick, C.M.; Purpura, M.; Moussa, A.; Townsend, J.R.; Lamprecht, M.; West, N.P.; Black, K.; et al. International Society of Sports Nutrition Position Stand: Probiotics. J. Int. Soc. Sports Nutr. 2019, 16, 62. [CrossRef] [PubMed]

25. Charreire, H.; Kesse-Guyot, E.; Bertrais, S.; Simon, C.; Chaix, B.; Weber, C.; Touvier, M.; Galan, P.; Hercberg, S.; Oppert, J.-M.J.B.J.o.N. Associations between dietary patterns, physical activity (leisure-time and occupational) and television viewing in middle-aged French adults. Brit. J. Nutr. 2011, 105, 902-910. [CrossRef] [PubMed]

26. Sheflin, A.M.; Melby, C.L.; Carbonero, F.; Weir, T.L. Linking dietary patterns with gut microbial composition and function. Gut Microbes 2017, 8, 113-129. [CrossRef]

27. Hsu, Y.J.; Chiu, C.C.; Li, Y.P.; Huang, W.C.; Te Huang, Y.; Huang, C.C.; Chuang, H.L. Effect of intestinal microbiota on exercise performance in mice. J. Strength. Cond. Res. 2015, 29, 552-558. [CrossRef] 
28. Nay, K.; Jollet, M.; Goustard, B.; Baati, N.; Vernus, B.; Pontones, M.; Lefeuvre-Orfila, L.; Bendavid, C.; Rué, O.; Mariadassou, M. Gut bacteria are critical for optimal muscle function: A potential link with glucose homeostasis. Am. J. Physiol. Endocrinol. Metab. 2019, 317, E158-E171. [CrossRef]

29. Okamoto, T.; Morino, K.; Ugi, S.; Nakagawa, F.; Lemecha, M.; Ida, S.; Ohashi, N.; Sato, D.; Fujita, Y.; Maegawa, H. Microbiome potentiates endurance exercise through intestinal acetate production. Am. J. Physiol. Endocrinol. Metab. 2019, 316, E956-E966. [CrossRef]

30. Barton, W.; Penney, N.C.; Cronin, O.; Garcia-Perez, I.; Molloy, M.G.; Holmes, E.; Shanahan, F.; Cotter, P.D.; O'Sullivan, O. The microbiome of professional athletes differs from that of more sedentary subjects in composition and particularly at the functional metabolic level. Gut 2018, 67, 625-633. [CrossRef]

31. LeBlanc, J.G.; Chain, F.; Martín, R.; Bermúdez-Humarán, L.G.; Courau, S.; Langella, P. Beneficial effects on host energy metabolism of short-chain fatty acids and vitamins produced by commensal and probiotic bacteria. Microb. Cell. Fact. 2017, 16, 79. [CrossRef] [PubMed]

32. Moreno-Pérez, D.; Bressa, C.; Bailén, M.; Hamed-Bousdar, S.; Naclerio, F.; Carmona, M.; Pérez, M.; González-Soltero, R.; Montalvo-Lominchar, M.G.; Carabaña, C. Effect of a protein supplement on the gut microbiota of endurance athletes: A randomized, controlled, double-blind pilot study. Nutrients 2018, 10, 337. [CrossRef] [PubMed]

33. Jang, L.G.; Choi, G.; Kim, S.W.; Kim, B.Y.; Lee, S.; Park, H. The combination of sport and sport-specific diet is associated with characteristics of gut microbiota: An observational study. J. Int. Soc. Sports Nutr. 2019, 16, 21. [CrossRef] [PubMed]

34. Keohane, D.M.; Woods, T.; O'Connor, P.; Underwood, S.; Cronin, O.; Whiston, R.; O'Sullivan, O.; Cotter, P.; Shanahan, F; Molloy, M.G. Four men in a boat: Ultra-endurance exercise alters the gut microbiome. J. Sci. Med. Sport 2019, 22, 1059-1064. [CrossRef]

35. Murtaza, N.; Burke, L.M.; Vlahovich, N.; Charlesson, B.; O’Neill, H.; Ross, M.L.; Campbell, K.L.; Krause, L.; Morrison, M. The effects of dietary pattern during intensified training on stool microbiota of elite race walkers. Nutrients 2019, 11, 261. [CrossRef]

36. Estaki, M.; Pither, J.; Baumeister, P.; Little, J.P.; Gill, S.K.; Ghosh, S.; Ahmadi-Vand, Z.; Marsden, K.R.; Gibson, D.L. Cardiorespiratory fitness as a predictor of intestinal microbial diversity and distinct metagenomic functions. Microbiome 2016, 4, 42. [CrossRef] [PubMed]

37. Bressa, C.; Bailén-Andrino, M.; Pérez-Santiago, J.; González-Soltero, R.; Pérez, M.; Montalvo-Lominchar, M.G.; Maté-Muñoz, J.L.; Domínguez, R.; Moreno, D.; Larrosa, M. Differences in gut microbiota profile between women with active lifestyle and sedentary women. PLoS ONE 2017, 12, e0171352. [CrossRef]

38. Bai, J.; Hu, Y.; Bruner, D. Composition of gut microbiota and its association with body mass index and lifestyle factors in a cohort of 7-18 years old children from the American Gut Project. Pediatr. Obes. 2019, 14, e12480. [CrossRef]

39. Durk, R.P.; Castillo, E.; Márquez-Magaña, L.; Grosicki, G.J.; Bolter, N.D.; Lee, C.M.; Bagley, J.R. Gut microbiota composition is related to cardiorespiratory fitness in healthy young adults. Int. J. Sport. Nutr. Exerc. Metab. 2019, 29, 249-253. [CrossRef]

40. Langsetmo, L.; Johnson, A.; Demmer, R.; Fino, N.; Orwoll, E.; Ensrud, K.; Hoffman, A.R.; Cauley, J.A.; Shmagel, A.; Meyer, K. The Association between Objectively Measured Physical Activity and the Gut Microbiome among Older Community Dwelling Men. J. Nutr. Health Aging 2019, 23, 538-546. [CrossRef]

41. Cani, P.D.; de Vos, W.M. Next-Generation Beneficial Microbes: The Case of Akkermansia muciniphila. Front. Microbiol. 2017, 8, 1765. [CrossRef] [PubMed]

42. Xu, Z.; Knight, R. Dietary effects on human gut microbiome diversity. Br. J. Nutr. 2015, 113, S1-S5. [CrossRef]

43. Hiippala, K.; Jouhten, H.; Ronkainen, A.; Hartikainen, A.; Kainulainen, V.; Jalanka, J.; Satokari, R. The potential of gut commensals in reinforcing intestinal barrier function and alleviating inflammation. Nutrients 2018, 10, 988. [CrossRef] [PubMed]

44. Koh, A.; De Vadder, F.; Kovatcheva-Datchary, P.; Bäckhed, F. From dietary fiber to host physiology: Short-chain fatty acids as key bacterial metabolites. Cell 2016, 165, 1332-1345. [CrossRef] [PubMed]

45. WHO. Global recommendations on physical activity for health. Geneva World Health Organ. 2010, 60.

46. Cintineo, H.P.; Arent, M.A.; Antonio, J.; Arent, S.M. Effects of Protein Supplementation on Performance and Recovery in Resistance and Endurance Training. Front. Nutr. 2018, 5, 83. [CrossRef] 
47. Russell, W.R.; Gratz, S.W.; Duncan, S.H.; Holtrop, G.; Ince, J.; Scobbie, L.; Duncan, G.; Johnstone, A.M.; Lobley, G.E.; Wallace, R.J.; et al. High-protein, reduced-carbohydrate weight-loss diets promote metabolite profiles likely to be detrimental to colonic health. Am. J. Clin. Nutr. 2011, 93, 1062-1072. [CrossRef]

48. Donati Zeppa, S.; Agostini, D.; Gervasi, M.; Annibalini, G.; Amatori, S.; Ferrini, F.; Sisti, D.; Piccoli, G.; Barbieri, E.; Sestili, P. Mutual Interactions among Exercise, Sport Supplements and Microbiota. Nutrients 2020, 12, 17. [CrossRef]

49. Ley, R.E.; Turnbaugh, P.J.; Klein, S.; Gordon, J.I. Human gut microbes associated with obesity. Nature 2006, 444, 1022-1023. [CrossRef]

50. Matsumoto, M.; Inoue, R.; Tsukahara, T.; Ushida, K.; Chiji, H.; Matsubara, N.; Hara, H. Voluntary running exercise alters microbiota composition and increases n-butyrate concentration in the rat cecum. Biosci. Biotechnol. Biochem. 2008, 72, 572-576. [CrossRef]

51. Choi, J.J.; Eum, S.Y.; Rampersaud, E.; Daunert, S.; Abreu, M.T.; Toborek, M. Exercise attenuates PCB-induced changes in the mouse gut microbiome. Environ. Health Perspect. 2013, 121, 725-730. [CrossRef]

52. Queipo-Ortuño, M.I.; Seoane, L.M.; Murri, M.; Pardo, M.; Gomez-Zumaquero, J.M.; Cardona, F.; Casanueva, F.; Tinahones, F.J. Gut microbiota composition in male rat models under different nutritional status and physical activity and its association with serum leptin and ghrelin levels. PLoS ONE 2013, 8, e65465. [CrossRef]

53. Liu, F.; Zhang, N.; Li, Z.; Wang, X.; Shi, H.; Xue, C.; Li, R.W.; Tang, Q. Chondroitin sulfate disaccharides modified the structure and function of the murine gut microbiome under healthy and stressed conditions. Sci. Rep. 2017, 7, 1-14. [CrossRef] [PubMed]

54. Evans, C.C.; LePard, K.J.; Kwak, J.W.; Stancukas, M.C.; Laskowski, S.; Dougherty, J.; Moulton, L.; Glawe, A.; Wang, Y.; Leone, V. Exercise prevents weight gain and alters the gut microbiota in a mouse model of high fat diet-induced obesity. PLoS ONE 2014, 9, e92193. [CrossRef] [PubMed]

55. Carbajo-Pescador, S.; Porras, D.; García-Mediavilla, M.V.; Martínez-Flórez, S.; Juarez-Fernández, M.; Cuevas, M.J.; Mauriz, J.L.; González-Gallego, J.; Nistal, E.; Sánchez-Campos, S. Beneficial effects of exercise on gut microbiota functionality and barrier integrity, and gut-liver crosstalk in an in vivo model of early obesity and non-alcoholic fatty liver disease. Dis. Model Mech. 2019, 12, dmm039206. [CrossRef] [PubMed]

56. Yuan, X.; Xu, S.; Huang, H.; Liang, J.; Wu, Y.; Li, C.; Yuan, H.; Zhao, X.; Lai, X.; Hou, S. Influence of excessive exercise on immunity, metabolism, and gut microbial diversity in an overtraining mice model. Scand. J. Med. Sci. Sports 2018, 28, 1541-1551. [CrossRef] [PubMed]

57. Huang, W.-C.; Chen, Y.-H.; Chuang, H.-L.; Chiu, C.-C.; Huang, C.-C. Investigation of the Effects of Microbiota on Exercise Physiological Adaption, Performance, and Energy Utilization Using a Gnotobiotic Animal Model. Front. Microbiol. 2019, 10, 1906. [CrossRef]

58. Lahiri, S.; Kim, H.; Garcia-Perez, I.; Reza, M.M.; Martin, K.A.; Kundu, P.; Cox, L.M.; Selkrig, J.; Posma, J.M.; Zhang, H. The gut microbiota influences skeletal muscle mass and function in mice. Sci. Transl. Med. 2019, 11, eaan5662. [CrossRef]

59. Kerksick, C.M.; Wilborn, C.D.; Roberts, M.D.; Smith-Ryan, A.; Kleiner, S.M.; Jäger, R.; Collins, R.; Cooke, M.; Davis, J.N.; Galvan, E. ISSN exercise \& sports nutrition review update: Research \& recommendations. J. Int. Soc. Sports Nutr. 2018, 15, 38. [CrossRef]

60. Maughan, R.J.; Burke, L.M.; Dvorak, J.; Larson-Meyer, D.E.; Peeling, P.; Phillips, S.M.; Rawson, E.S.; Walsh, N.P.; Garthe, I.; Geyer, H. IOC consensus statement: Dietary supplements and the high-performance athlete. Int. J. Sport Nutr. Exerc. Metab. 2018, 28, 104-125. [CrossRef]

61. Ducray, H.; Globa, L.; Pustovyy, O.; Roberts, M.; Rudisill, M.; Vodyanoy, V.; Sorokulova, I. Prevention of excessive exercise-induced adverse effects in rats with Bacillus subtilis BSB3. J. Appl. Microbiol. 2020, 128, 1163. [CrossRef] [PubMed]

62. Ünsal, C.; Ünsal, H.; Ekici, M.; Koc Yildirim, E.; Üner, A.; Yildiz, M.; Güleş, Ö.; Ekren Aşici, G.; Boyacioğlu, M.; Balkaya, M. The effects of exhaustive swimming and probiotic administration in trained rats: Oxidative balance of selected organs, colon morphology, and contractility. Physiol. Int. 2018, 105, 309-324. [CrossRef]

63. Lollo, P.; Cruz, A.; Morato, P.; Moura, C.; Carvalho-Silva, L.; Oliveira, C.A.F.d.; Faria, J.; Amaya-Farfan, J. Probiotic cheese attenuates exercise-induced immune suppression in Wistar rats. J. Dairy Sci. 2012, 95, 3549-3558. [CrossRef]

64. Lollo, P.C.B.; de Moura, C.S.; Morato, P.N.; Cruz, A.G.; de Freitas Castro, W.; Betim, C.B.; Nisishima, L.; José de Assis, F.F.; Junior, M.M.; Fernandes, C.O. Probiotic yogurt offers higher immune-protection than probiotic whey beverage. Food Res. Int. 2013, 54, 118-124. [CrossRef] 
65. Appukutty, M.; Ramasamy, K.; Rajan, S.; Vellasamy, S.; Ramasamy, R.; Radhakrishnan, A. Effect of orally administered soy milk fermented with Lactobacillus plantarum LAB12 and physical exercise on murine immune responses. Benef. Microbes 2015, 6, 491-496. [CrossRef]

66. Coffey, V.G.; Hawley, J.A. Concurrent exercise training: Do opposites distract? J. Physiol. 2017, 595, $2883-2896$. [CrossRef] [PubMed]

67. Rondanelli, M.; Faliva, M.A.; Perna, S.; Giacosa, A.; Peroni, G.; Castellazzi, A.M. Using probiotics in clinical practice: Where are we now? A review of existing meta-analyses. Gut Microbes 2017, 8, 521-543. [CrossRef]

68. Hao, Q.; Dong, B.R.; Wu, T. Probiotics for preventing acute upper respiratory tract infections. Cochrane Database Syst. Rev. 2015, CD006895. [CrossRef]

69. Gleeson, M.; Bishop, N.C.; Oliveira, M.; Tauler, P. Daily probiotic's (Lactobacillus casei Shirota) reduction of infection incidence in athletes. Int. J. Sport Nutr. Exerc. Metab. 2011, 21, 55-64. [CrossRef]

70. Kekkonen, R.A.; Vasankari, T.J.; Vuorimaa, T.; Haahtela, T.; Julkunen, I.; Korpela, R. The effect of probiotics on respiratory infections and gastrointestinal symptoms during training in marathon runners. Int. J. Sport Nutr. Exerc. Metab. 2007, 17, 352-363. [CrossRef]

71. West, N.P.; Pyne, D.B.; Cripps, A.W.; Hopkins, W.G.; Eskesen, D.C.; Jairath, A.; Christophersen, C.T.; Conlon, M.A.; Fricker, P.A. Lactobacillus fermentum (PCC(R)) supplementation and gastrointestinal and respiratory-tract illness symptoms: A randomised control trial in athletes. Nutr. J. 2011, 10, 30. [CrossRef] [PubMed]

72. Lamprecht, M.; Bogner, S.; Schippinger, G.; Steinbauer, K.; Fankhauser, F.; Hallstroem, S.; Schuetz, B.; Greilberger, J.F. Probiotic supplementation affects markers of intestinal barrier, oxidation, and inflammation in trained men; a randomized, double-blinded, placebo-controlled trial. J. Int. Soc. Sports Nutr. 2012, 9, 45. [CrossRef] [PubMed]

73. Roberts, J.D.; Suckling, C.A.; Peedle, G.Y.; Murphy, J.A.; Dawkins, T.G.; Roberts, M.G. An Exploratory Investigation of Endotoxin Levels in Novice Long Distance Triathletes, and the Effects of a Multi-Strain Probiotic/Prebiotic, Antioxidant Intervention. Nutrients 2016, 8, 733. [CrossRef] [PubMed]

74. Haywood, B.A.; Black, K.E.; Baker, D.; McGarvey, J.; Healey, P.; Brown, R.C. Probiotic supplementation reduces the duration and incidence of infections but not severity in elite rugby union players. J. Sci. Med. Sport 2014, 17, 356-360. [CrossRef]

75. De Oliveira, E.P.; Burini, R.C.; Jeukendrup, A. Gastrointestinal complaints during exercise: Prevalence, etiology, and nutritional recommendations. Sports Med. 2014, 44 (Suppl. 1), S79-S85. [CrossRef]

76. West, N.P.; Pyne, D.B.; Cripps, A.; Christophersen, C.T.; Conlon, M.A.; Fricker, P.A. Gut Balance, a synbiotic supplement, increases fecal Lactobacillus paracasei but has little effect on immunity in healthy physically active individuals. Gut Microbes 2012, 3, 221-227. [CrossRef]

77. Shing, C.M.; Peake, J.M.; Lim, C.L.; Briskey, D.; Walsh, N.P.; Fortes, M.B.; Ahuja, K.D.; Vitetta, L. Effects of probiotics supplementation on gastrointestinal permeability, inflammation and exercise performance in the heat. Eur. J. Appl. Physiol. 2014, 114, 93-103. [CrossRef]

78. Nieman, D.C.; Wentz, L.M. The compelling link between physical activity and the body's defense system. J. Sport Health Sci. 2019, 8, 201-217. [CrossRef]

79. Nieman, D.C. Exercise, upper respiratory tract infection, and the immune system. Med. Sci. Sports Exerc. 1994, 26, 128-139. [CrossRef]

80. Colbey, C.; Cox, A.J.; Pyne, D.B.; Zhang, P.; Cripps, A.W.; West, N.P. Upper Respiratory Symptoms, Gut Health and Mucosal Immunity in Athletes. Sports Med. 2018, 48, 65-77. [CrossRef]

81. Cox, A.J.; Pyne, D.B.; Saunders, P.U.; Fricker, P.A. Oral administration of the probiotic Lactobacillus fermentum VRI-003 and mucosal immunity in endurance athletes. Br. J. Sports Med. 2010, 44, 222-226. [CrossRef] [PubMed]

82. Salarkia, N.; Ghadamli, L.; Zaeri, F.; Sabaghian Rad, L. Effects of probiotic yogurt on performance, respiratory and digestive systems of young adult female endurance swimmers: A randomized controlled trial. Med. J. Islam. Repub. Iran 2013, 27, 141-146.

83. West, N.P.; Horn, P.L.; Pyne, D.B.; Gebski, V.J.; Lahtinen, S.J.; Fricker, P.A.; Cripps, A.W. Probiotic supplementation for respiratory and gastrointestinal illness symptoms in healthy physically active individuals. Clin. Nutr. 2014, 33, 581-587. [CrossRef] [PubMed] 
84. Michalickova, D.; Minic, R.; Dikic, N.; Andjelkovic, M.; Kostic-Vucicevic, M.; Stojmenovic, T.; Nikolic, I.; Djordjevic, B. Lactobacillus helveticus Lafti L10 supplementation reduces respiratory infection duration in a cohort of elite athletes: A randomized, double-blind, placebo-controlled trial. Appl. Physiol. Nutr. Metab. 2016, 41, 782-789. [CrossRef] [PubMed]

85. Strasser, B.; Geiger, D.; Schauer, M.; Gostner, J.M.; Gatterer, H.; Burtscher, M.; Fuchs, D. Probiotic Supplements Beneficially Affect Tryptophan-Kynurenine Metabolism and Reduce the Incidence of Upper Respiratory Tract Infections in Trained Athletes: A Randomized, Double-Blinded, Placebo-Controlled Trial. Nutrients 2016, 8, 752. [CrossRef]

86. Kellmann, M.; Bertollo, M.; Bosquet, L.; Brink, M.; Coutts, A.J.; Duffield, R.; Erlacher, D.; Halson, S.L.; Hecksteden, A.; Heidari, J.; et al. Recovery and Performance in Sport: Consensus Statement. Int. J. Sports Physiol. Perform. 2018, 13, 240-245. [CrossRef]

87. EFSA Panel on Nutrition; Novel Foods and Food Allergens (EFSA NDA Panel); Turck, D.; Castenmiller, J.; De Henauw, S.; Hirsch-Ernst, K.; Kearney, J.; Knutsen, H.; Maciuk, A.; Mangelsdorf, I.; et al. Guidance on the scientific requirements for health claims related to muscle function and physical performance. EFSA J. 2018, 16. [CrossRef]

88. Chen, Y.M.; Wei, L.; Chiu, Y.S.; Hsu, Y.J.; Tsai, T.Y.; Wang, M.F.; Huang, C.C. Lactobacillus plantarum TWK10 Supplementation Improves Exercise Performance and Increases Muscle Mass in Mice. Nutrients 2016, 8, 205. [CrossRef] [PubMed]

89. Hsu, Y.J.; Huang, W.C.; Lin, J.S.; Chen, Y.M.; Ho, S.T.; Huang, C.C.; Tung, Y.T. Kefir Supplementation Modifies Gut Microbiota Composition, Reduces Physical Fatigue, and Improves Exercise Performance in Mice. Nutrients 2018, 10, 862. [CrossRef]

90. Soares, A.D.N.; Wanner, S.P.; Morais, E.S.S.; Hudson, A.S.R.; Martins, F.S.; Cardoso, V.N. Supplementation with Saccharomyces boulardii Increases the Maximal Oxygen Consumption and Maximal Aerobic Speed Attained by Rats Subjected to an Incremental-Speed Exercise. Nutrients 2019, 11, 2352. [CrossRef]

91. Huang, W.C.; Hsu, Y.J.; Li, H.; Kan, N.W.; Chen, Y.M.; Lin, J.S.; Hsu, T.K.; Tsai, T.Y.; Chiu, Y.S.; Huang, C.C. Effect of Lactobacillus Plantarum TWK10 on Improving Endurance Performance in Humans. Chin. J. Physiol. 2018, 61, 163-170. [CrossRef] [PubMed]

92. Huang, W.C.; Lee, M.C.; Lee, C.C.; Ng, K.S.; Hsu, Y.J.; Tsai, T.Y.; Young, S.L.; Lin, J.S.; Huang, C.C. Effect of Lactobacillus plantarum TWK10 on Exercise Physiological Adaptation, Performance, and Body Composition in Healthy Humans. Nutrients 2019, 11, 2836. [CrossRef] [PubMed]

93. Carbuhn, A.F.; Reynolds, S.M.; Campbell, C.W.; Bradford, L.A.; Deckert, J.A.; Kreutzer, A.; Fry, A.C. Effects of Probiotic (Bifidobacterium longum 35624) Supplementation on Exercise Performance, Immune Modulation, and Cognitive Outlook in Division I Female Swimmers. Sports 2018, 6, 116. [CrossRef] [PubMed]

94. Marshall, H.; Chrismas, B.C.R.; Suckling, C.A.; Roberts, J.D.; Foster, J.; Taylor, L. Chronic probiotic supplementation with or without glutamine does not influence the eHsp72 response to a multi-day ultra-endurance exercise event. Appl. Physiol. Nutr. Metab. 2017, 42, 876-883. [CrossRef]

95. Townsend, J.R.; Bender, D.; Vantrease, W.C.; Sapp, P.A.; Toy, A.M.; Woods, C.A.; Johnson, K.D. Effects of Probiotic (Bacillus subtilis DE111) Supplementation on Immune Function, Hormonal Status, and Physical Performance in Division I Baseball Players. Sports 2018, 6, 70. [CrossRef] [PubMed]

96. Toohey, J.C.; Townsend, J.R.; Johnson, S.B.; Toy, A.M.; Vantrease, W.C.; Bender, D.; Crimi, C.C.; Stowers, K.L.; Ruiz, M.D.; VanDusseldorp, T.A.; et al. Effects of Probiotic (Bacillus subtilis) Supplementation During Offseason Resistance Training in Female Division I Athletes. J. Strength. Cond. Res. 2018, 10. [CrossRef]

97. Ibrahim, N.S.; Muhamad, A.S.; Ooi, F.K.; Meor-Osman, J.; Chen, C.K. The effects of combined probiotic ingestion and circuit training on muscular strength and power and cytokine responses in young males. Appl. Physiol. Nutr. Metab. 2018, 43, 180-186. [CrossRef] [PubMed]

98. Lee, M.C.; Hsu, Y.J.; Chuang, H.L.; Hsieh, P.S.; Ho, H.H.; Chen, W.L.; Chiu, Y.S.; Huang, C.C. In Vivo Ergogenic Properties of the Bifidobacterium longum OLP-01 Isolated from a Weightlifting Gold Medalist. Nutrients 2019, 11, 2003. [CrossRef]

99. Lee, M.C.; Hsu, Y.J.; Ho, H.H.; Hsieh, S.H.; Kuo, Y.W.; Sung, H.C.; Huang, C.C. Lactobacillus salivarius Subspecies salicinius SA-03 is a New Probiotic Capable of Enhancing Exercise Performance and Decreasing Fatigue. Microorganisms 2020, 8, 545. [CrossRef] 
100. Gill, S.K.; Allerton, D.M.; Ansley-Robson, P.; Hemmings, K.; Cox, M.; Costa, R.J. Does Short-Term High Dose Probiotic Supplementation Containing Lactobacillus casei Attenuate Exertional-Heat Stress Induced Endotoxaemia and Cytokinaemia? Int. J. Sport Nutr. Exerc. Metab. 2016, 26, 268-275. [CrossRef]

101. Gill, S.K.; Teixeira, A.M.; Rosado, F.; Cox, M.; Costa, R.J. High-Dose Probiotic Supplementation Containing Lactobacillus casei for 7 Days Does Not Enhance Salivary Antimicrobial Protein Responses to Exertional Heat Stress Compared With Placebo. Int. J. Sport Nutr. Exerc. Metab. 2016, 26, 150-160. [CrossRef]

102. Vaisberg, M.; Paixao, V.; Almeida, E.B.; Santos, J.M.B.; Foster, R.; Rossi, M.; Pithon-Curi, T.C.; Gorjao, R.; Momesso, C.M.; Andrade, M.S.; et al. Daily Intake of Fermented Milk Containing Lactobacillus casei Shirota (Lcs) Modulates Systemic and Upper Airways Immune/Inflammatory Responses in Marathon Runners. Nutrients 2019, 11, 1678. [CrossRef] [PubMed]

103. Valimaki, I.A.; Vuorimaa, T.; Ahotupa, M.; Kekkonen, R.; Korpela, R.; Vasankari, T. Decreased training volume and increased carbohydrate intake increases oxidized LDL levels. Int. J. Sports Med. 2012, 33, $291-296$. [CrossRef] [PubMed]

104. Pugh, J.N.; Sparks, A.S.; Doran, D.A.; Fleming, S.C.; Langan-Evans, C.; Kirk, B.; Fearn, R.; Morton, J.P.; Close, G.L. Four weeks of probiotic supplementation reduces GI symptoms during a marathon race. Eur. J. Appl. Physiol. 2019, 119, 1491-1501. [CrossRef] [PubMed]

105. Huang, W.C.; Wei, C.C.; Huang, C.C.; Chen, W.L.; Huang, H.Y. The Beneficial Effects of Lactobacillus plantarum PS128 on High-Intensity, Exercise-Induced Oxidative Stress, Inflammation, and Performance in Triathletes. Nutrients 2019, 11, 353. [CrossRef] [PubMed]

106. Jager, R.; Purpura, M.; Stone, J.D.; Turner, S.M.; Anzalone, A.J.; Eimerbrink, M.J.; Pane, M.; Amoruso, A.; Rowlands, D.S.; Oliver, J.M. Probiotic Streptococcus thermophilus FP4 and Bifidobacterium breve BR03 Supplementation Attenuates Performance and Range-of-Motion Decrements Following Muscle Damaging Exercise. Nutrients 2016, 8, 642. [CrossRef] [PubMed]

107. Jager, R.; Shields, K.A.; Lowery, R.P.; De Souza, E.O.; Partl, J.M.; Hollmer, C.; Purpura, M.; Wilson, J.M. Probiotic Bacillus coagulans GBI-30, 6086 reduces exercise-induced muscle damage and increases recovery. PeerJ 2016, 4, e2276. [CrossRef]

108. Mazani, M.; Nemati, A.; Baghi, A.N.; Amani, M.; Haedari, K.; Alipanah-Mogadam, R. The effect of probiotic yoghurt consumption on oxidative stress and inflammatory factors in young females after exhaustive exercise. J. Pak. Med. Assoc. 2018, 68, 1748-1754.

109. Muhamad, A.; Gleeson, M. Effects of a 14-strain probiotics supplement on salivary antimicrobial proteins at rest and in response to an acute bout of prolonged exercise. Int. J. Sports Sci. 2014, 4, 7. [CrossRef]

110. O’Brien, K.V.; Stewart, L.K.; Forney, L.A.; Aryana, K.J.; Prinyawiwatkul, W.; Boeneke, C.A. The effects of postexercise consumption of a kefir beverage on performance and recovery during intensive endurance training. J. Dairy Sci. 2015, 98, 7446-7449. [CrossRef]

111. Salehzadeh, K. The effects of probiotic yogurt drink on lipid profile, CRP and record changes in aerobic athletes. Int. J. Life Sci. 2015, 9, 32-37. [CrossRef]

112. Inoue, T.; Kobayashi, Y.; Mori, N.; Sakagawa, M.; Xiao, J.Z.; Moritani, T.; Sakane, N.; Nagai, N. Effect of combined bifidobacteria supplementation and resistance training on cognitive function, body composition and bowel habits of healthy elderly subjects. Benef. Microbes 2018, 9, 843-853. [CrossRef] [PubMed]

113. Peake, J.M.; Neubauer, O.; Della Gatta, P.A.; Nosaka, K. Muscle damage and inflammation during recovery from exercise. J. Appl. Physiol. 2017, 122, 559-570. [CrossRef] [PubMed]

114. Dupuy, O.; Douzi, W.; Theurot, D.; Bosquet, L.; Dugue, B. An Evidence-Based Approach for Choosing Post-exercise Recovery Techniques to Reduce Markers of Muscle Damage, Soreness, Fatigue, and Inflammation: A Systematic Review with Meta-Analysis. Front. Physiol. 2018, 9, 403. [CrossRef]

115. Gepner, Y.; Hoffman, J.R.; Shemesh, E.; Stout, J.R.; Church, D.D.; Varanoske, A.N.; Zelicha, H.; Shelef, I.; Chen, Y.; Frankel, H.; et al. Combined effect of Bacillus coagulans GBI-30, 6086 and HMB supplementation on muscle integrity and cytokine response during intense military training. J. Appl. Physiol. 2017, 123, 11-18. [CrossRef] [PubMed]

116. Jager, R.; Zaragoza, J.; Purpura, M.; Iametti, S.; Marengo, M.; Tinsley, G.M.; Anzalone, A.J.; Oliver, J.M.; Fiore, W.; Biffi, A.; et al. Probiotic Administration Increases Amino Acid Absorption from Plant Protein: A Placebo-Controlled, Randomized, Double-Blind, Multicenter, Crossover Study. Probiotics Antimicrob. Proteins 2020. [CrossRef] 
117. Foster, J.A.; Rinaman, L.; Cryan, J.F. Stress \& the gut-brain axis: Regulation by the microbiome. Neurobiol. Stress 2017, 7, 124-136. [CrossRef]

118. Vitellio, P.; Chira, A.; De Angelis, M.; Dumitrascu, D.L.; Portincasa, P. Probiotics in Psychosocial Stress and Anxiety. A Systematic Review. J. Gastrointestin. Liver Dis. 2020, 29, 77-83. [CrossRef]

119. Sashihara, T.; Nagata, M.; Mori, T.; Ikegami, S.; Gotoh, M.; Okubo, K.; Uchida, M.; Itoh, H. Effects of Lactobacillus gasseri OLL2809 and $\alpha$-lactalbumin on university-student athletes: A randomized, double-blind, placebo-controlled clinical trial. Appl. Physiol. Nutr. Metab. 2013, 38, 1228-1235. [CrossRef]

120. Sawada, D.; Kuwano, Y.; Tanaka, H.; Hara, S.; Uchiyama, Y.; Sugawara, T.; Fujiwara, S.; Rokutan, K.; Nishida, K. Daily intake of Lactobacillus gasseri CP2305 relieves fatigue and stress-related symptoms in male university Ekiden runners: A double-blind, randomized, and placebo-controlled clinical trial. J. Funct. Foods 2019, 57, 465-476. [CrossRef]

(C) 2020 by the authors. Licensee MDPI, Basel, Switzerland. This article is an open access article distributed under the terms and conditions of the Creative Commons Attribution (CC BY) license (http://creativecommons.org/licenses/by/4.0/). 